\title{
Small- and Medium-Size Enterprise Financing in Eastern Europe
}

\author{
Leora F. Klapper \\ Development Research Group \\ The World Bank \\ 1818 H Street, NW \\ Washington, DC 20433 \\ (202) 473-8738 \\ lklapper@worldbank.org \\ Virginia Sarria-Allende \\ Columbia Business School \\ 3022 Broadway \\ New York, NY 10027 \\ (212) 861-5171 \\ vs189@columbia.edu \\ Victor Sulla \\ Development Research Group \\ The World Bank \\ 1818 H Street, NW \\ Washington, DC 20433 \\ (202) 473-3617 \\ vsulla@worldbank.org
}

World Bank Policy Research Working Paper 2933, December 2002

The Policy Research Working Paper Series disseminates the findings of work in progress to encourage the exchange of ideas about development issues. An objective of the series is to get the findings out quickly, even if the presentations are less than fully polished. The papers carry the names of the authors and should be cited accordingly. The findings, interpretations, and conclusions expressed in this paper are entirely those of the authors. They do not necessarily represent the view of the World Bank, its Executive Directors, or the countries they represent. Policy Research Working Papers are available online at http://econ.worldbank.org.

The authors thank the Europe and Central Asia (ECA) region of the World Bank for their financial support. The authors also thank Qing-Hua Zhao and Tony Sihsobhon for their generous help and Rodrigo Chaves, Thorsten Beck, Asli Demirguc-Kunt, Patrick Honohan, Inessa Love, Paul Siegelbaum, and Dimitri Vittas for helpful comments. This work was completed while Virginia Sarria-Allende was visiting the World Bank. 


\begin{abstract}
$\underline{\text { Abstract: }}$
There is currently a large interest in understanding firms' acess to finance, and the financing of smalland medium-sized enterprises (SMEs) in particular. However, the financing patterns of SMEs across countries is not well understood; for example, little is known about the relative importance of equity, debt, and inter-firm financing for SMEs across countries. This paper uses the AMADEUS database, which includes financial information on over 97,000 private and publicly traded firms in 15 Eastern and Central European countries. The Amadeus database allows us the opportunity to provide a new analysis of the general financing patterns of private firms across a large sample of Eastern European countries. Our summary statistics show that the size of the SME sector (as measured by the percentage of total employment) in Eastern European countries is smaller than what we observe in most developed economies. Although we find in almost every country in our sample a large number of SMEs as a percentage of total firms, the SMEs in Eastern Europe are generally small and hire few employees. However, SMEs seem to constitute the most dynamic sector of the Eastern European economies, relative to large firms. In general, the SME sector comprises relatively younger, more highly leveraged, and more profitable and faster growing firms. This suggests that a new type of firm is emerging in transition economies that is more market- and profit-oriented. But at the same time, these firms appear to have financial constraints that impede their access to long-term financing and ability to grow.
\end{abstract}




\section{Introduction}

For most of the $19^{\text {th }}$ and $20^{\text {th }}$ centuries, large corporations were considered the primary and driving force of economic and technological progress. Very large corporations dominated research and development (R\&D) and the introduction of innovations, and experienced major improvements in production efficiency. The exploitation of economies of scale and scope were considered to be the driving force of economic development. As Schumpeter (1942) proclaimed, "What we have got to accept is that the large-scale enterprise has come to be the most powerful engine of progress". Since the contribution of small and medium size enterprises (SMEs) was small, economists considered this sector less important.

Beginning in the 1970s, however, large manufacturing firms in key industries began to loose competitiveness and a number of important empirical studies began to document the critical role of SMEs. For example, Acs (1984) argued that newer and smaller firms entered sectors as "agents of change". Studies using direct measures of innovative activity - such as measures of new products and processes - replaced older measures (such as R\&D) and showed that innovative activity was introduced by small firms and not the larger incumbents (see Acs and Audrestsch, 1988 and 1990). SMEs also began to play an important role as efficient providers of intermediate goods and services to large firms. Many papers showed that developed countries that encouraged entrepreneurship and SMEs had higher economic growth. ${ }^{1}$

Previous studies also showed the shift in the industrial structure away from large corporations and towards SMEs during the 1980s and 1990's. ${ }^{2}$ Several explanations have been offered to account for this structural change. For example, Audretsch and Thurik (2000) suggested that the increase in

\footnotetext{
${ }^{1}$ For example, see Schimitz (1989), Acs (1992), Calderon and Nickel (1998) and Audretsch and Thurik (2000).

${ }^{2}$ For example, see Acs and Audretsch (1993), Loveman and Senegenberger (1991) and Thurik (1996).
} 
the level of education and business skills in the United States increased entrepreneurship and new firms. Others have focused on the inflexibility of large conglomerates to react to globalization and new technology and innovations, which encouraged managers and other insiders at large firms to leave and compete in a more efficient environment.

However, the underlying story of the introduction of SMEs in Eastern European countries seems to be quite different. Unlike the United States, which experienced a natural birth of new, small firms, the SME sector in Eastern European countries emerged as a result of the privatization and breakup of large state-owned enterprises, as well as through a large number of new, generally very small firms that came as a consequence of the market liberalization process. ${ }^{3}$ We see in Eastern Europe a unique role for SMEs during "transitional" periods of change. The restructuring and downsizing of large firms, the privatization of public utilities and other large companies, the outsourcing of many support services, and the vertical fragmentation of production are all forces that promoted the creation and expansion of SMEs.

A number of recent papers have discussed the characteristics and role of SMEs in developed countries, but little has been said about SMEs in Eastern Europe. ${ }^{4}$ Given the unique nature of the financial development and market structure in Eastern European countries, we would expect to see some distinctions in the firm characteristics and financing choices of SMEs in these countries, relative to previous studies. The AMADEUS database - which includes financial information on over 5 million registered firms in Eastern and Western Europe - offers an excellent opportunity to study the firm characteristics of the SME sector in a wide range of countries. In this first summary paper we focus our analysis on the characteristics of over 97,000 firms in a sample of Eastern

\footnotetext{
${ }^{3}$ See Svejnar (2002).

${ }^{4}$ There have been a number of country-specific World Bank surveys of SMEs in Eastern Europe. For example, we discuss in Section 3 a survey of SMEs in Romania by Chaves, Sanchez, Schor and Tesliuc (2001) and a survey of Russian firms by Broadman and Recanatini, 2001.
} 
European countries, with special focus on SMEs (that represent about $82 \%$ of the total sample). ${ }^{5} \mathrm{We}$ provide some evidence on the main differences between SMEs and large corporations in 15 Eastern European countries.

We also include a discussion of our cross-country findings on the firm and country characteristics that affect firms' access to finance and the financing of SMEs in particular. There is an extensive literature examining the capital structure choices of firms in developed and developing countries, although most studies exclude small firms. ${ }^{6}$ In this paper we provide a new analysis of the general financing patterns of private firms across countries. With the caveat, however, that we are providing neither an exhaustive nor rigorous analysis of capital structure, but only showing some key preliminary results that should only be seen as a starting point for future research.

The paper proceeds as follows. Section 2 describes the Amadeus database, the financial and descriptive variables available for each firm, and limitations of the data. Section 3 reviews the previous literature relating to the SME sectors in particular and the development of financial markets in Eastern Europe in general. Section 4 provides summary statistics and a discussion of the Amadeus data, by age, size, and leverage. Section 6 discusses future avenues for research and concludes.

\footnotetext{
5 Throughout this paper we use the European convention of defining the SME sector as firms with less than 250 employees.

${ }^{6}$ For example, Rajan and Zingales (1995) and Booth, Aivazian, Demirguc-Kunt, and Maksimovic (2001) study the capital structure of developed and developing countries, respectively, although these papers use only a sample of publicly-traded firms.
} 


\section{Description of the Amadeus Data}

The data used in this paper come from the Amadeus-Bureau Van Dijk database, which includes firm-level data on over 5 million private and publicly owned non-financial firms in 34 European countries, including 15 Eastern European countries. Our analysis in this paper focuses only on the 15 Eastern European and Central Asian "transition" economies: five countries of the former Soviet Union - Russia, Ukraine, Estonia, Lithuania and Latvia - and ten other former socialist countries - Bosnia-Herzegovina, Bulgaria, Croatia, the Czech Republic, Hungary, Poland, Romania, Slovakia, Slovenia and Yugoslavia. The total sample of Eastern European firms includes over 500,000 enterprises. $^{7}$

The Amadeus database is created by collecting standardized data received from 50 vendors across Europe. The local source for this data is generally company registrar offices, which require all incorporated firms to submit annual filings. The database includes firm-level accounting data in standardized financial format comprising 22 balance sheet items, 22 profit and loss income statement items, and 21 financial ratios. A list of all available financial information is provided in Appendix 2. These financial profiles are augmented with descriptive information including: official national identification number, address, telephone, fax, website, legal form, year of incorporation, senior managers, auditors, number of employees, quoted/unquoted indicator, industry and activity codes and, when available, a trade description in the local language and English. Furthermore, Amadeus includes detailed ownership information, including the names and country(s) of origins of all block shareholders (with greater than $5 \%$ shareholding). Supplemental information is also available on subsidiaries.

\footnotetext{
7 This includes about 300,000 very small Romanian firms.
} 
From 1990 to 1996, Amadeus collected data on only large and listed companies (similar to WorldScope and GlobalVantage coverage). Since then the coverage has continued to gradually increase and since 1998 has included extended coverage for small and medium-size enterprises in Eastern European countries. However, we include in this analysis only firms with 10 or more employees, since Amadeus coverage of very small firms varies with country-level filing requirements. For example, some countries (such as the Ukraine and Russia) do not require soleproprietors to report financial information. We believe that this cutoff - consistent with the inclusion criteria used by Amadeus for their main database sold to commercial customers - corrects for the sample-biases in the number of smallest firms. After excluding firms with missing employment data and firms with employment less than 10, our final sample includes about 97,000 firms. ${ }^{8}$

Some additional caveats are necessary. Although all firms in our sample have basic financial data (i.e. total assets and total liabilities), nevertheless, detailed coverage of capital structure and performance varies across countries. ${ }^{9}$ For example, firms in Latvia and Russia are missing turnover variables and firms in Slovenia and Croatia only report total liabilities and do not include a breakdown of their debt structures (such as maturity). In addition, determining the legal "type" of firms (publicly traded, private or state owned, etc.) is a serious challenge of the data. Firms include country-specific descriptions and more than 150 legal type categories exist across countries. To date, we have only investigated these legal definitions in order to identify less than 1,000 state-owned enterprises and non-profit organizations that we have exclude from our sample. ${ }^{10}$ The number of state-owned firms in our sample is small because the Amadeus data is intended to cover only

\footnotetext{
${ }^{8}$ Appendix 1 shows, for comparison, summary statistics of firms with less than 10 employees.

${ }^{9}$ We exclude from our sample firms missing basic financial information such as total assets and total liabilities.

${ }^{10}$ We also excluded a small number of financial intermediaries, since their balance sheets and income statements are not comparable to non-financial firms.
} 
privately owned firms. Our final sample includes all non-financial privately owned and publicly traded firms.

We use 1999 data for our analysis, which is the year with the maximum data coverage. Our final sample size is 97,107 enterprises. Table 1 shows the cross-country coverage of the Amadeus database in 1999 by country, size, and sector. We see that some countries like Romania, Bulgaria, and the Ukraine include a large number of firms, while other countries like Bosnia-Herzegovina, Lithuania, and Slovenia include a relatively small number of firms. There are a number of possible explanations for the variation in the number of firms across countries. First, the actual number of active enterprises may be a result of differences in the population and size and level of development of the private sector across countries. A second reason is that our data includes only firms in the "formal sector" that are incorporated and pay company registration fees and taxes, and the size of the informal SME sector may be larger in some countries.

Table 1 also shows the size of the SME sector across countries - which we define as firms with less than 250 employees - and as a percentage of total firms and population. We find that a large percentage of firms are categorized as SMEs: On average, $82 \%$ of firms in Eastern Europe are SMEs, ranging from very low percentages in Russia and the Ukraine, $48.98 \%$ and 54.33\%,

respectively, to $97.8 \%$ in Estonia. ${ }^{11}$ In Section 4 we explore possible country-level explanations for these differences.

\section{Literature Review}

\subsection{Access to Financing by the SME Sector}

\footnotetext{
${ }^{11}$ We also see a very close correlation between the SME percentages and rankings (1-15) of the SME sector as a percentage of firms and as a percentage of the total population (64\% and $95 \%$, respectively).
} 
Previous literature has studied SME access to financing and shown that SMEs have different capital structures than large firms. For example, Cressy and Olofsson (1997) found that smaller businesses have lower fixed-to-total assets ratios, higher ratios of current liabilities to total assets and are financially more risky. Scherr, et al. (1990) and Hamilton and Fox (1998) suggested that smaller companies limit their issuance of outside equity in order not to reduce control of their firms.

The literature has also discussed reasons why it is harder for SMEs to access debt financing. For example, Berger and Udell (1995) found that small and young firms - with generally shorter banking relationships - pay higher interest rates and are more likely to be required to pledge collateral. Satio and Villanueva (1981) and Peel and Wilson (1996) showed that in general SMEs have higher costs and reduced access to financing because of the information asymmetries associated with newer, smaller firms. Furthermore, Levy (1993) concluded that restricted access to financial services slows the growth of SMEs. In comparison to these previous studies, the summary statistics for our sample of Eastern European countries show that firms in transition countries often behave in a different way.

Previous studies also show the unique challenges to SMEs to access outside borrowing and suggest country-specific environmental factors - such as creditor rights and legal efficiency - that affect SME access to financing. This literature suggests that banks should be able to make more loans to smaller, riskier firms in countries that offer stronger creditor rights - such as the priority of secured creditors in the case of default. For example, Brush and Chaganti (1998) found that ownership structure and creditors rights protection have significant positive influence on the size and performance of SMEs. Furthermore, Beck Demirguc-Kunt, and Maksivmovic (2002) showed that small firms are most credit constrained as a result of underdeveloped financial and legal systems and 
higher corruption. We expect legal development to affect SME access to financing in our sample of Eastern European countries.

\subsection{Financial Development in Eastern Europe}

There is a small, but growing, body of literature that studies various financial characteristics of Eastern European countries. One of the few cross-country studies is Gros and Suhrchke (2000), who did a comprehensive analysis of the similarities and difference between transition countries in Eastern Europe and other comparable developing economies. They highlighted some characteristics common to all transition economies at the initial stage of reform such us a concentration of firms in the industrial/ manufacturing sector, the underdevelopment of financial systems, and low legal and governance standards. Throughout our analysis we find patterns that are substantially consistent with this initial description.

A recent World Bank report also performed a broad analysis of the development of the corporate sector of most Eastern European and former Soviet Union (FSU) countries during the transition from communist to market economies. ${ }^{12}$ This report described the size and characteristics of the SME sector across countries and showed the gain to GDP that could be reached by reallocating resources from the old state enterprises to the dynamic new SME sector. This paper measured the size of the SME sector as the percentage of total employment attributable to the SME sector in 1995 , and found results that are generally consistent with ours, although they report higher percentages of SMEs across all countries. However, we would expect our findings to be somewhat different since we use a base year of 1999 and because we only include the sample of firms included in Amadeus, which may not include very small firms. However, our data confirms their general results; for

12 "Transition, The First Ten Years, Analysis and Lessons for Eastern Europe and the Former Soviet Union", 2002. 
example, the paper mentioned the particular dynamism of SMEs in the case of Poland and Hungary, where structural reforms generated a favorable climate for the entry of new enterprises. Accordingly, we find in these countries relatively high levels of firm performance and the lowest percentages of distressed firms.

However, most studies have sampled just one or a few transition economies and focused on specific aspects of their financial development. For example, a recent paper by Broadman and Recanatini (2002) analyzed the privatization process in Russia and its impact on the labor market. Their evidence suggests that the downsizing of Russian firms was only partially completed and, consequently, the overstaffing typical of the socialist regime has not been adequately resolved. Our data support this result - we find that Russian firms have comparatively high levels of median employment and that the SME sector shows relatively scarce participation as a percentage of total employment. Our evidence also confirms their result that Russian firms showed a positive correlation between firm size and profitability.

Other studies have highlighted the success stories of country-specific initiatives. For example, a report "Labor Market Adjustment in Estonia" (1998) discussed the "massive increase in worker flows" seen during the Estonian reform. This report argued that SMEs had been the driving force behind the job creation process, specifically those concentrated in the service and trade-oriented sectors. In agreement with this claim, we find that the Estonian SME sector contributed $71 \%$ of the total employment and is typified by very small (and profitable) firms with a median of only 21 employees (after excluding all firms with less than 10 employees).

Other studies have discussed the effect of the development of the lending environment on access to financing. For example, Egerer (1995) studied bank lending in the Czech Republic. He found that firms had difficulty borrowing, since corporate performance is not transparent and weak 
creditor rights and collateral laws discourage collateral-based lending. He suggested that ownership connections between banks and firms could be beneficial in transition economies to overcome these information asymmetries and weak laws. Although we cannot identify bank ownership, we document in the next section that Eastern European firms in our sample rarely use long-term financing.

Finally, given the large share of Romanian firms in our sample (about 28\%), it is especially relevant to comment on a recent paper that studied Romanian financial markets (Chaves, Sanchez, Schor and Tesliuc, 2001). Although this paper specifically focused on the financial accessibility of rural economic agents (enterprises and households), we think that many of the paper's result apply more universally to the corporate sector (although the agriculture sector represents only $12 \%$ of our sample). For example, the paper describes the impediments that all sectors face in getting efficient financial services and, once again, how real access to investment opportunities are closely related to the degree of ownership and other associations with financial intermediaries. The paper suggests that part of the reason for the low level of financing in Romania is the inability to borrow long-term, which is caused by inflation and weak legal protection. The report also discusses the overall low profitability levels that characterize Romanian firms (when measured as ROA), which is consistent with our results. ${ }^{13}$

Lastly, it is worth commenting on some related research that has used the Amadeus database. There have been some studies using the Amadeus data but, to our knowledge, none of them has had the more comprehensive approach that is pursued in this report. Koke and Salem (2000) study a cross section of ten CEE countries to test whether corporate capital structure works as a disciplining device. Their intuition is that firms more in need to downsize, due to lower levels of productivity and

${ }^{13}$ Additional country-specific studies include S. Kukar (1996) for Slovenia, V. Cieslar (1996) for the Czech Republic, and G. Minassian G. and S. Totev (1996) for Bulgaria. 
profitability, would be more likely to do so if the external pressure is large, i.e. if there is a high dependence on outside borrowing. Budina et al. (undated) used the Amadeus data to study access to financing in Bulgarian firms. They found low levels of liquidity constraints, which they interpreted as not necessarily associated with low equity premiums (as would be the explanation in developed countries) but rather as a result of the presence of soft-budget constraints and an inefficient financial sector.

\section{Summary Statistics of Firms in Eastern Europe}

We begin with an overview of the total sample of firms in order to capture the general characteristics of the region and specificities of each individual country. As described in Section 3, our study focuses on a sample of 15 Eastern European countries for the year 1999. Since our analysis includes five countries of the former Soviet Union, we also compare the characteristics of firms in these countries with those in the remaining countries. Median summary statistics, by country, are presented in Table 2. We discuss median summary statistics, since although we have attempted to identify and delete incorrect data observations, there are still a number of large outliers in our sample. We show mean summary statistics for all tables in the Annex, which are consistent with the mendian values. Table 3 shows summary statistics for all firms for all countries and disaggregated by size and age.

The median firm size has great variation across countries, as measured by number of employees, total assets, and total sales. However, the median age is less than 10 years for all countries (except for Bosnia-Herzegovina), suggesting that most firms were created during the transition period. Although many of the firms - particularly in the FSU countries - may be spin-offs 
of former state-owned companies, this still implies that the majority of firms are operating under a relatively new corporate structure.

Table 2 (and the first column of Table 3) also demonstrate that most countries in our sample exhibit relatively low use of outside financing, as shown by leverage ratios (measured as the ratio of liabilities-to-equity and debt-to-equity) with medians about equal to 0.92 and 0.84 , respectively. In the Ukraine - at the lowest extreme of the distribution - total liabilities-to-equity and total debt-to equity equal 0.29 and 0.27 , respectively. Firms in 6 out of 15 countries have total liabilitiy ratios less than one, which suggests that the firm borrows less than $\$ 1$ for every $\$ 2$ invested in equity. This is in comparison to a median leverage ratio of 1.73 for the Amadeus sample of Western European firms. We also find almost no use of long-term debt (median short-term-to-total debt ratios equal one in almost all countries), which may be the result of the underdevelopment of the banking sector, poor collateral law, and weak collateral registries.

Median profitability ratios (measured by return on assets, ROA, and return on equity, ROE) are 0.05 and 0.06 , respectively, which is about equal to the median ratios across developed Western European countries. However, median 1-year sales growth is negative in all but one country for which 1998 data is available; in comparison, median 1-year sales growth rates are positive in all Western European countries. This combination of weak performance plus low access to financing suggests a risk of prolonged corporate contraction.

We also find that firms across many countries have low levels of inter-firm trade financing as shown by account payable-to-equity ratios close to zero - with the exception of Hungary (and, to a lesser degree, the Czech Republic, Poland and Romania.) This may be explained by a number of interesting reasons - first, the overall low levels of growth and leverage suggest that firms may not have sufficient internal funds or access to external borrowing to finance the extension of trade credit. 
Second, in many developing countries trade credit is predominately offered by large domestic and multinational firms that can finance their extension of trade credit in foreign markets. With the exception of the Central European countries such as Hungary and Poland - where we see the use of trade credit - there is not yet a large foreign presence in the region.

Finally, low-levels of trade credit is consistent with the findings of Demirguc-Kunt and Maksimovic (2001) that the development of the banking system and the efficiency of the legal environment predict the use of trade credit. Indeed, we find that those countries with higher use of trade credit (Hungary, Romania, and Poland) also have relatively more developed financial markets and legal efficiency (see Table 6). Furthermore, Table 7 shows negative correlations in all countries with available data between trade credit (as a percentage of total liabilities) and total debt-to-equity ratios. This implies that with the caveat that the overall level of trade credit use if small, we find evidence consistent with the finding in previous literature that trade credit is used as a substitute for bank financing in countries with weak financial institutions (Petersen and Rajan, 1997, and Fisman and Love, 2002).

\subsection{Summary Statistics by Age}

Table 4 shows summary statistics by three firm age categories: 0-3, 4-10, and greater than 10 . Overall, the firms in our sample could be considered as relatively young - about $15 \%$ of the firms have been created during the last three years and, as expected in transition countries, almost $65 \%$ of all firms have only existed as such for less than 10 years. Even though there is broad cross-country variation, FSU countries appear to exhibit the highest participation of young firms (for example, over $20 \%$ of total firms in Estonia, Lithuania, Russia, and Slovakia were incorporated in the last 3 years). 
Median age in the total sample ranges from 5 to 17, (or 5 to 9 if we exclude Bosnia-Herzegovina), whereas FSU firms tend to be even younger, and the median range goes from only 5 to 6 years.

We find that new firms are in general relatively smaller firms across the total sample. For example, we show that $85 \%$ of firms age $0-3$ are SMEs (compared to $59 \%$ of firms over 10 years). Median size, measured by total assets, varies across the sample from tiny firms in Romania with assets valued at about $\$$ US 200,000 , to a median firm size of almost US\$ 5 million in the case of Poland. ${ }^{14}$ If we define size as the number of employees (as we do for most of our analysis), we also find a strong relationship between firm size and age, where all but two countries have median employment in new firms of less than 125 employees (only Ukraine and Russia, two countries of the former Soviet Union, show much higher employment with median employment of 186 and 285, respectively).

The contribution to total employment generated by young firms also presents wide crosscountry variation. However, looking across the total sample, the subset of youngest firms ( $0-3$ years) contributes only about $15 \%$ of total employment (the largest contribution is seen in Romania and the Ukraine, where this group generates $19 \%$ of total employment). ${ }^{15}$ Nevertheless, in 11 out of 15 countries included in the sample, firms in their first 10 years generate over $50 \%$ of total employment. In addition, we find that new firms exhibit higher 1-year growth rates, as shown quite dramatically in Table 3. We find that new firms have over $8 \%$ annual growth compared to $-12 \%$ and $-11 \%$-year growth for firms age 3-10 and over 10 years, respectively.

Again, this suggests the importance of firms that have been established during the transition period.

\footnotetext{
${ }^{14}$ The asset value of Romanian firms can certainly be influenced by the Romanian accounting law that requires all assets to be booked at their historical value and does not allow revaluations to take place (see Chaves et al, 2001).

${ }^{15}$ See Klapper and Sulla (2002) for a more detailed study of the Ukraine.
} 
We also find that although absolute leverage ratios are low across the region, smaller and younger firm are in general more leveraged, which suggests that leverage ratios tend to decrease with size and age. As shown in Table 7, we find significantly negative correlations between firm age and the ratio of total debt-to-equity in all countries. Furthermore, most debt in all countries is concentrated in the short-term, which implies that there is very little access to (or demand for) longterm financing. This may be as a result of weak property and collateral laws, as well as the concetration of firms in the service sector, which generally implies that firms have less fixed-assets to use as collateral.

A final interesting feature is the higher concentration of smaller and younger firms in the service sector, while the relatively larger and older firms are more characteristic of the industrial sector. One explanation may be that during the Soviet era the service sector was underemphasized and almost non-existent; therefore, this sector may have provided the greatest opportunities for new entrepreneurs. In addition, this may reflect the low costs necessary to enter many service sectors versus the difficulties for new firms to access the long-term financing necessary to purchase equipment and machinery needed to enter the manufacturing sector.

\subsection{Summary Statistics by Size}

Table 4 shows summary statistics by firm size. We use the European convention of identifying SMEs as firms with less than 250 employees and provide summary statistics that compare SMEs and large firms. Since the collapse of communism, the development of the SME sector has become one of the principal economic reform priorities for domestic politicians and outside bilateral and multilateral providers of financial aid. For example, the European Bank for Reconstruction and Development (EBRD) was established to support private sector development in formerly communist 
countries and along with the European Union and the World Bank has emerged as an important provider of assistance to SME development within reforming countries.

An immediate result of the liberalization of the business environment and the assistance of a multitude of international programs is that the SME sector in Eastern Europe has developed at a very fast pace and the growth of the SME sector in the post-communist countries has been heralded is one of the prominent success stories of East European economies. ${ }^{16}$ However, many new SMEs have been created from the break-up of larger inefficient state enterprises and from the privatization of smaller units of large (often formally state-owned) firms and these "new" SMEs have relatively small sizes and low survival rates. ${ }^{17}$ Although our data does not allow us to study firm exits, our sample does confirm that the median employment of individual SMEs is quite low. In half of the countries that we study, which account for more than $60 \%$ of SMEs in the sample, the median number of employees is less than 50 .

Although in Eastern Europe the percentage of the number of SMEs compared to the total number of firms may be high, the percentage of employment that is attributable to the SME sector varies considerably. For examples, in Russia the participation of SMEs in the total employment is only $8 \%$, but in Estonia we find that SMEs employ $71 \%$ of total employees - the size of the SME sector is not homogeneous even among countries of the FSU. Across countries, the average percentage of employees in the SME sector is about 30\%. In comparison, if we look at the SME sector in developed countries, we find that the share in total employment is much higher and goes

\footnotetext{
${ }^{16}$ See Levitsky (1996) and the OECD (1996).

${ }^{17}$ See Pransikar (1998), Svejnar (2002), and Smith (1998).
} 
from approximately $53 \%$ for the US and Canada and $57 \%$ for Germany to more than $80 \%$ for Belgium. $^{18}$

A primary reason for the underdevelopment of the SME sector is the legacy of very large Soviet firms that employed very high numbers of employees and the virtual elimination of small firms and entrepreneurship. In addition, another reason that these countries have small SME sectors (as measured by employment) could be financial credit constraints - which would imply that SMEs were unable to access outside financing necessary to grow. For example, Pissarides (1999) showed that credit constraints limited the growth of SMEs in the CEE countries. We see in our data sample that firms do not have access to long-term debt (unless we assume that firms voluntarily decided not to borrow long-term). Most financing is concentrated in the short run and with limited participation of trade credit; consequently, we can presume that SMEs are limited to high levels of contractual short-term debt.

In addition, leverage ratios - measured as the ratio of liabilities to equity and debt to equity vary considerably among SMEs in the cross section of Eastern European countries, going from very low levels in the Ukraine to very indebted SMEs in Croatia (with debt-to-equity ratios of 0.39 and 1.99 , respectively). Nonetheless, there seems to be a clear pattern in the relation between leverage and size - in examining the comparison between SMEs and large firms, we find that in every country in our sample, leverage reduces with size. This evidence is shown quite convincingly in Figure 1.

According to some studies on privatized firms in transition economies (for example, Harper, 1999), relatively larger firms face more difficulties improving performance after privatization. We would expect that firms with lower profits should have ess outside borrowing, since they are less able to repay the interest and principle. Although we do not have information on privatized versus

${ }^{18}$ Data on the percentage of employment attributable to the SME sector in developed countries is provided by the OECD. 
non-privatized firms - but assuming the likely inclusion of privatized firms in our sample - this suggests that we should expect to find a negative relation between size and performance. We examine profitability ratios within our sample and find a wide cross-country variation, but consistently the highest levels of performance are found in relatively small, highly leveraged firms. For example, ROE shows a very persistent negative relation with size - ROE is largest for small firms in all countries - which reasonably relates to the leverage pattern described in previous research.

Next, we test some theoretical predictions on the relationship between country characteristics and the development of the SME sector. As shown in Table 6 we calculate simple correlations between the size of the SME sector (proxied by the percentage of total and employment attributable to SMEs) and indicators of macroeconomic growth (logged GDP per capita and the 1-year growth rate of GDP), financial development (private capital as a percentage of GDP and the percentage of state-owned and foreign banking assets) and legal and judicial efficiency (the "rule of law" index from Kaufman and Kraay, 2001). We find a positively significant relationship between a business environment that promotes access to financing and the size of the SME sector. For example, we find that a better legal environment - that allows banks to write strong contracts and have such contracts enforced in a court of law - increases the percentage of SMEs.

We also find that greater foreign bank assets is related to a higher percentage of SMEs, which may suggest that foreign bank entry encourages domestic banks to lend "downstream" to smaller customers. This is consistent with Clarke et al. (2001) who found that foreign bank penetration improves financing conditions for firms of all sizes. We also find a negative relation with stateowned bank assets, which suggests that the SME sector is larger in countries with less state-owned bank penetration, which implies greater market-based lending behavior. Finally, we find that the size 
of the SME sector is larger in countries with higher real economic development and greater GDP growth. Although we cannot interpret causality, this suggests interdependence between the size of the SME sector and growth - whereas greater growth should create more opportunities for SMEs to provide goods and services to larger firms and a more prosperous population, it may also be the case that the SME sector contributes substantially to real growth. We leave a more rigorous study of this question to future research.

Overall, we find that the SME sector is associated with young firms. We also find that the SME sector has relatively higher leverage ratios, suggesting that larger firms either have less access to outside financing or less investment opportunities. At the firm level, SMEs exhibit very low levels of employment; however, since the number of SMEs in some countries is so large, there are some countries where the SME sector makes a big contribution to the total employment generation. Finally, our results provide evidence of a positive correlation between leverage and firms' profitability. In other words, we find that the SME sector in Eastern Europe is relatively more profitable and has greater access to financing, as compared to large firms. This implies that SMEs may have growth opportunities that can be realized with access to borrowing. This suggests that promoting the development and growth of firms in the SME sector in Eastern Europe may be a way to develop a stronger corporate sector in the future.

To summarize our results:

- We find, in general, a positive relationship between firm size and age.

- We find a positive link between profitability and leverage (short-term debt), which suggests a relationship between profitability and access to working capital financing.

- We find that younger firms have higher leverage and growth. 
- We find that older and larger firms have smaller cash ratios, which suggest that these firms are more dependent on internal sources of financing.

- Finally, we find that smaller and younger firms are likely to be in the services sector.

\section{Tests of Capital Structure Theory}

Although a thorough analysis of the capital structure of firms in Eastern Europe exceeds the scope of this paper, we have used a simple regression analysis in order to further explore the relations between debt ratios and some firm characteristic. Our intention is only to provide a first glance at the behavior of firms in Eastern Europe and leave a more rigorous empirical study of capital structure to future research. A distinctive novelty of this sudy is our examination of financial structure in a sample of private and publicly traded firms, where the vast majority of firms are privately owned.

We evaluate the key relations between short-term and long-term debt ratios and firm characteristics as pedicted by principal theories of capital structure. Table 8 summarizes the predicted results according to these varying theories. First, the Static Trade Off Theory (Myers, 1977), which argues that firms decide between the trade off of the benefits of tax-shields offered by borrowing new debt against the costs of bankruptcy that highly leveraged firms are more likely to face. For example, this theory predicts that leverage should be higher in larger firms with stronger performance and higher marginal taxes. Second, the Pecking Order Theory (Myers and Majluf, 1984), which assumes a situation in which entrepreneurs who are currently managing some assets need to raise funds to undertake a new project whose profitability is known only to them. Under this scenario with asymmetric information, raising external capital is costly, because the mangers are unable to convince investors of the true expected value of the project. This theory argues that firms should rely first on internal, rather than external, sources of funds and, when external financing is 
necessary, they should prefer to raise debt before equity; in other words, leverage should be lower in firms with greater retained earnings. Eastern European firms are an ideal sample to test this theory, since many countries suffer from weak transparency and disclosure requirements and poor accounting standards, which exacerbate the information asymmetries.

Third, we include the Risk Shifting Hypothesis (Jensen and Meckling, 1976), which argues that shareholders of highly leveraged firms may invest suboptimally - to the detriment of bondholders - in negative present value projects that generate high benefits to the stockholders in good states and large loses to debtholders in bad states. Closely related is the Underinvestment Theory (Myers, 1977), which similarly argues that shareholders of highly leveraged firms have incentives to pass up some positive net present value investments, since the return from investment would primarily favor debtholders, even though the cost of investments is assumed by the equityholders. Both of these theories predict that bondholders will only invest in firms with high collateral values in order to receive some compensation in the bad states. This suggests that leverage ratios should be higher in firms with greater collateral values.

Finally, the Free Cash Flow Theory (Jensen, 1986) and Agency Cost Hypothesis (Titman and Wessels, 1988, Stulz, 1990) examine the impact of the manager-shareholder agency problems on the capital structure of firms. These theories argue that debt should be used to limit managerial discretion in firms with greater profitability (discretionary cash) and less growth opportunities. These theories predict a positive relation between profitability and leverage and a negative relationship between leverage and growth opportunities. Lastly, we compare our results to previous cross-country studies of firm behavior in emerging markets (such as Booth, Aivazian, Demirguc-Kunt and Maksimovic, 2001). 
Table 9 shows our regression results for total debt, short-term debt, and long-term debt ratios. However, we add the caveat that it may be difficult to interpret our predictions of debt maturity, since as previously discussed; the firms in our sample are characterized by extremely low levels of longterm financing. It may be the case that in some of these countries less-developed banking systems, weak collateral law, and poor credit information registries reduce the availability of long-term debt and therefore, short-term debt may be used as a substitute for long-term financing. Consequently, our results may also be explained by additional "supply-side” hypotheses.

We use the natural log of total Sales as a measure of SIZE and the number of years since incorporation to measure AGE. We use return on equity (ROE) to measure profitability (PROFIT) this measure is preferable to ROA because of the high concentration of service firms in our sample and use the 1-year growth rate of sales to measure GROWTH. TANGIBILITY is measured as the ratio of fixed assets to total assets and NDTS measures non-debt tax shields, estimated as the ratio of depreciation to total assets. We also include industry dummies (indicating manufacturing and service firms) and country dummies in all regressions.

As predicted by the Static Trade Off theory, we find a positive relation between SIZE and total, short-, and long-term financing. This implies that bigger firms have better access to long-term financing, as measured by the natural log of sales and employment (not shown). In addition, we find a negative relationship between AGE and all measures of debt. This is consistent with our summary statistics that suggest that younger (more profitable) firms are more likely to have greater debt outstanding.

As discussed above, capital structure theory predicts an inverse relation between growth opportunities and long-term debt and a positive relation of growth opportunities and short-term financing. We find a persistent and significantly positive relation between growth and all types of 
debt. This result could also be interpreted as a supply side phenomenon, where firms showing more promising growth opportunities get better access to external financing. The relation between profitability and debt maturity is consistent across theories: First, we find that firms use internal funds before using long-term debt (but not before short-term debt), which may be explained by the relative inaccessibility of long-term debt in the region. Second, we find that total and short-term debt are positively related to profitability, which might be the most important factor in accessing outside financing in countries with weak collateral laws.

We also find a negative relation between tangibility and total and short-term debt and a positive relationship between tangibility and long-term debt. These results are consistent with most theories on capital structure that suggest that firms without fixed-assets to use for collateral are unable to access long-term financing. For example, theories predict that higher collateral value reduces bankruptcy costs (Static Trade Off Theory), allows firms' access to risk free debt (Pecking Order Theory), and increases opportunities for perks consumption (Free Cash Flow Theory). This is also highly consistent with the evidence in previous debt maturity literature that found that firms with higher compositions of fixed assets might borrow long-term debt in preference to short-term debt (see Demirguc-Kunt and Maksimovic, 1999). Finally, we find a significantly negative relation between the depreciation to total assets ratio and all debt types, which provides support for the Static Trade Off theory, according to which firms with high levels of non-debt tax shields would be less likely to look for additional tax benefits.

These results highlight the uniqueness of the Eastern European region - such as our finding that younger firms have greater debt usage - as well as the robustness of capital structure theory as it applies even in transition countries. Our econometric tests support our intuition based on the summary statistics and correlation tests. These findings underline the relationship between access to 
debt financing and a new wave of young, profitable, and growing firms that are emerging in the region.

\section{Conclusion and Remarks}

The Amadeus database provides us for the first time with the opportunity to study the firmlevel behavior of small and private firms across a large sample of Eastern European countries. Our summary statistics suggest that the size of the SME sector (as measured by the percentage of total employment) in Eastern European countries is smaller than what we observe in most developed economies (such as the US, Germany, and Belgium). Although we find in almost every country in our sample a large number of SMEs as a percentage of total firms, the SMEs in Eastern Europe are generally very small and employ very few individuals. We suggest that this evidence may support findings in previous research that SMEs in Eastern Europe suffer from financial constraints - i.e. low absolute amounts of outside financing - that impede their growth. Furthermore, neither SMEs nor large firms in these countries seem able to attain reasonable levels of growth.

However, we also find evidence suggesting that SMEs seem to constitute the most dynamic sector of Eastern European economies, relative to larger firms. In general, the SME sector comprises relatively younger, more highly leveraged, and more profitable firms. This suggests that a new type of firm is emerging in transition economies that is more market- and profit-oriented. But at the same time, these SMEs are only borrowing short-term debt, which appears to be the only type of financing that these firms can access.

Some policy implications can be easily derived from this analysis. Since SMEs appear to be the healthiest segment of the corporate sector, government policies should encourage the growth of this sector, which could help jump-start the growth of a more dynamic and profitable private sector. 
Among the policy objectives should be improving the macroeconomic environment; developing an efficient legal and judicial system that allows contract enforcement, M\&A, and efficient resolution of financial distress; permitting foreign bank and corporate entry; and development of the financial sector and debt markets. For example, one initiative should be to improve access to long-term debt, which requires overall improvements in financial development and depth. Our analysis also suggests that further growth of the SME sector would probably follow improvements in the legal and regulatory environment.

The Amadeus data will allow us to study many new and interesting research questions. For example, this data can be used to study reasons for differences in firm growth across firm sizes and countries; capital structure and debt maturity; the relationship between performance and access to financing; and explanations for variations in cash holdings. ${ }^{19}$ We expect that this paper is only a preview of important and relevant research to come. For example, by identifying country and firm characteristics that promote the growth of SMEs, we can develop a roadmap of policies to develop the small business sector. This research can provide powerful policy tools to operational staff working on the growth and development of the private sector in developing countries.

\footnotetext{
${ }^{19}$ For a greater discussion of proposed future work see Demirguc-Kunt, A. and T. Beck, 2002,
} "Research Proposal: Small and Medium Enterprises: Overcoming Growth Constraints". 


\section{References}

Acs Z., 1984, The Changing Structure of the US Economy Lessons from the Steel Industry, New York: Praeger.

Acs, Z. and Audretsch D., 1988, Innovation in Large and Small Firms: An Empirical analysis, American Economic Review, 78(4), September, 678-690.

Acs A., 1992, Small Business Economics: A Global Perspective, Challenge v 35, n6, 38-44.

Acs Z. and Audretsch D., 1993, Small Firms and Entrepreneurship: And East-West Perspective, Cambridge, Cambridge University Press.

Audretsch, D. and A. Thurik, 2000, Capitalism and Democracy in the 21st Century: From the Managed to the Entrepreneurial Economy, Journal of Evolutio nary Economics 10(1), 17-34.

Beck, T., A. Demirguc-Kunt, V. Maksimovic, 2002, Financial and Legal Constraints to Firm Growth: Does Size Matter?, World Bank working paper.

Berger, A and G. Udell, 1995, Relationship Lending and Lines of Credit in Small Firm Finance, Journal of Business, 351-81.

Booth L., Aivazian V., Demirguc-Kunt A, and Maksimovic V., 2001, Capital Structures in Developing Countries, The Journal of Finance, vol. 56, no. 1, pp. 87-130.

Barth, J., G. Caprio, and R. Levine, 2001, The Regulation and Supervision of Banks Around the World: A New Database, World Bank working paper.

Broadman H. and Recanatini F., 2001, Is Russia Restructuring? New Evidence on Job Creation and Destruction, World Bank working paper.

Brush, C. G. and R. Chaganti, 1998, Businesses without Glamour? An Analysis of Resources on Performance by Size and Age in Small Service and Retail Firms, Journal of Business Venturing 14, 233-257.

Budina N., Garretsen H. and Jong E., Liquidity Constraints and Investment in Transition Economies: The Case of Bulgaria, Working Paper (undated).

Calderon, I., M. Nickel, 1998, Innovacion Tecnologica y Supervivencia en el Sector de Prensa Diaria en Espana (with English summary), Economia Industrial v0, n1, 151-64.

Chaves R., Sanchez S., Schor S. and Tesliuc E., 2001, Financial Markets, Credit Constraints, and Investment in Rural Romania, World Bank Technical Paper N. 499. 
Clarke, G., R. Cull, M. Martinez-Peria, 2001, Does Foreign Bank Penetration Reduce Access to Credit in Developing Countries? Evidence From Asking Borrowers, World Bank working paper No. 2716.

Cieslar V., 1996, The Czech-Saxony Cross-Border Dimension of Regional Transition in the Czech Republic, Eastern European Economics, Armonk.

Cressy, R. and C. Olofsson, 1997, European SME Financing: An Overview, Small Business Economics 9, 87-96.

Demirguc-Kunt A. and Maksimovic V., 1999, Institutions, Financial Markets and Firm Debt Maturity, Journal of Financial Economics, v54, n3, 295-336.

Demirguc-Kunt A. and Maksimovic V., 2001, Firms as Financial Intermediaries: Evidence from Trade Credit Data, World Bank working paper.

Egerer R., 1995, Capital Markets, Financial Intermediaries, and Corporate Governance: An Empirical Assessment of the Top Ten Voucher Fund, Working paper.

Raymond, F. and I. Love, 2003, Trade Credit, Financial Intermediary Development and Industry Growth, Journal of Finance, Forthcoming.

Fazekas K., 1996, Types of Microregions, Dispersion of Unemployment, and Local Employment Development in Hungary, Eastern European Economics; Armonk.

Gros D. and Suhrcke M, 2000, Ten Years After: What is Special About Transition Countries?, European Bank Working Paper N. 56.

Hamilton, R. T. and M. A. Fox, 1998, The Financing Preferences of Small Firm Owners, International, Journal of Entrepreneurial Behavior \& Research 4(3), 239-248.

Harper J. and Krehbiel T., 1999, An Empirical Investigation of the Relationship between Ownership Structure and Operating Performance of Newly Privatized Czech Firms, Advances in Financial economics, Vol. 4. Stamford, 19-101.

Jensen M. and Meckling W., 1976, Theory of the Firm: Managerial Behavior, Agency Costs and Ownership Structure, Journal of Financial Economics, v3, n4, 305-60.

Kaufmann, D. and A. Kraay, 2001, Governance Research Indicators (dataset), World Bank.

Klapper, L. and V. Sulla, 2002, Amadeus Analysis of the Ukraine, working paper.

Koke F. and Salem T., 2000, Corporate Finance and Restructuring: Evidence from Central and Eastern Europe, ZEW Discussion Paper N. 00-21. 
Kukar S., 1996, Regional Policy in Slovenia: Results, Problems, and Alternatives, Eastern European Economics; Armonk.

Levitsky, J. (ed.), 1996, Small Business in Transition Economies, London: ITDG Publications.

Levy B., 1993, Obstacles to Developing Indigenous Small and Medium Enterprise: an empirical Assessment, The World Bank Economic Review 7 (1), 65-68.

Loveman G. and Sengenberger W., 1991, The Re-emergence of Small-Scale Production: An International Perspective, Small Business Economics, 3 (1), 1-38.

Myers S., 1977, Determinants of Corporate Borrowing, Journal of Financial Economics, v5, n2 14775.

Myers S. and Majluf N. S., 1984, Corporate Financing and Investment Decisions When Firms Have Information That Investors Do Not Have, Journal of Financial Economics, v13, n2, 187-221.

Peel M. and Wilson N., 1996, Working Capital and Financial Management Practices in the Small Form Sector, International Small Business Journal, Vol. 14, 52-68.

Petersen M. and Rajan R.G., 1997, Trade Credit: Theories and Evidence, Review of Financial Studies, vol 10, no 3, 551-692.

Pissarides F., 1999, Is Lack of Funds the Main Obstacle to Growth? EBRD's Experience with Small and Medium Sized Business in Central and Eastern Europe, Journal of Business Venturing 14, 519539.

Rajan R. G. and Zingales L., 1997, Trade Credit: Theories and Evidence, Review of Financial Studies, vol 10, no 3, 661-692.

Rajan R. G. and Zingales L., 1998, Financial Dependence and Growth, American Economic Review v88, n3, 556-86.

Saito K. and Villanueva D., 1981, Transactions Costs of Credit to the Small-Scale Sector in the Philippines, Economic Development and Cultural Change, (29), 3.

Scherr, 1990, Financing the Small Firm Startup: Determinants of Debt Use, Proceedings Second Annual Small Firm Finance Research Symposium.

Schmitz J.A., 1989, Imitation, Entrepreneurship, and Long-run Growth, Journal of Political Economy, 97: 721-739.

Schumpeter, J., 1942, Capitalism, Socialism and Democracy, New York: Harper and Row.

Smith, A., 1998, Reconstructing the Regional Economy: Industrial Transformation and Regional Development in Slovakia, Cheltenham, U.K.: Edward Elgar. 
Svejnar J., 2002, Transition Economies: Performance and Challenges, Journal of Economic Perspectives, v6, n1, 3-28.

Thurik, A.R., 1996, Small Firms, Entrepreneurship and Economic Growth, In: Acs Z., Carlsson B. and Thurik A.R. (eds) Small Business in The Modern Economy, 126-152.

Titman S. and Wessels R., 1988, The Determinants of Capital Structure Choice, The Journal of Finance, Vol. 43, No. 1, pp. 1-19.

Totev S., 1996, The Bulgarian Economy in Transition, Eastern European Economics; Armonk.

World Bank Report, 1998, Transition Economies, Labor and Employment, Labor Market Adjustment in Estonia.

World Bank Report, 2002, Transition, The First Ten Years, Analysis and Lessons for Eastern Europe and the Former Soviet Union. 


\section{Table 1: Amadeus Coverage of Eastern European firms, by Industry and Employment, 1999}

Sample includes all nonfinancial, private, and publicly traded firms with more than 10 employees. SMEs are defined as firms with less than 250 employees.

\begin{tabular}{|c|c|c|c|c|c|c|c|c|c|c|}
\hline & \multicolumn{4}{|c|}{ All Firms } & \multicolumn{4}{|c|}{ SMEs } & \multicolumn{2}{|c|}{ SMEs as a Percentage of: } \\
\hline & All Firms & Agriculture & Industry & Service & All Firms & Agriculture & Industry & Service & All Firms & Population \\
\hline All Countries & 97,107 & 10,293 & 42,933 & 34,270 & 79,723 & 8,027 & 33,636 & 30,264 & $82.10 \%$ & $0.025 \%$ \\
\hline Bosnia-Herzegovina & 935 & 96 & 451 & 355 & 812 & 86 & 367 & 328 & $86.84 \%$ & $0.021 \%$ \\
\hline Bulgaria & 15,941 & 2,261 & 6,540 & 6,516 & 15,123 & 2,225 & 5,976 & 6,310 & $94.87 \%$ & $0.184 \%$ \\
\hline Croatia & 4,271 & 165 & 1,760 & 2,140 & 3,838 & 143 & 1,498 & 2,000 & $89.86 \%$ & $0.088 \%$ \\
\hline Czech Republic & 5,500 & 322 & 2,152 & 2,723 & 4,301 & 268 & 1,422 & 2,367 & $78.20 \%$ & $0.042 \%$ \\
\hline Estonia & 5,783 & 620 & 1,956 & 2,459 & 5,656 & 613 & 1,889 & 2,413 & $97.80 \%$ & $0.408 \%$ \\
\hline Hungary & 4,260 & 165 & 1,863 & 891 & 3,614 & 127 & 1,448 & 774 & $84.84 \%$ & $0.036 \%$ \\
\hline Latvia & 1,864 & 44 & 650 & 1,089 & 1,634 & 37 & 532 & 999 & $87.66 \%$ & $0.068 \%$ \\
\hline Lithuania & 774 & 19 & 314 & 425 & 638 & 12 & 209 & 403 & $82.43 \%$ & $0.017 \%$ \\
\hline Poland & 9,484 & 132 & 4,960 & 3,835 & 6,746 & 108 & 3,202 & 3,120 & $71.13 \%$ & $0.017 \%$ \\
\hline Romania & 27,335 & 3,158 & 15,186 & 8,704 & 25,535 & 3,037 & 13,943 & 8,305 & $93.42 \%$ & $0.114 \%$ \\
\hline Russia & 2,889 & 77 & 1,476 & 1,038 & 1,415 & 21 & 568 & 645 & $48.98 \%$ & $0.001 \%$ \\
\hline Slovakia & 1,221 & 80 & 493 & 553 & 831 & 67 & 239 & 448 & $68.06 \%$ & $0.015 \%$ \\
\hline Slovenia & 297 & 5 & 165 & 113 & 202 & 4 & 93 & 93 & $68.01 \%$ & $0.010 \%$ \\
\hline Ukraine & 14,326 & 2,992 & 3,822 & 2,591 & 7,783 & 1,170 & 1,526 & 1,373 & $54.33 \%$ & $0.016 \%$ \\
\hline Yugoslavia (FR) & 2,227 & 157 & 1,145 & 838 & 1,595 & 109 & 724 & 686 & $71.62 \%$ & $0.015 \%$ \\
\hline
\end{tabular}


Table 2A: Median Summary Statistics, All Firms, 1999

Sample includes all nonfinancial, private, and publicly traded firms with more than 10 employees. Current Ratio equals the ratio of current assets to current liabilities. Cash Ratio equals the ratio of cash to current liabilities. ROE equals the ratio of net income to equity. ROA equals the ratio of EBIT to total assets.

\begin{tabular}{|c|c|c|c|c|c|c|c|c|c|c|c|c|c|c|c|}
\hline All Firms & $\begin{array}{c}\text { Bosnia - } \\
\text { Herzegovina }\end{array}$ & Bulgaria & Croatia & $\begin{array}{c}\text { Czech } \\
\text { Republic }\end{array}$ & Estonia & Hungary & Latvia & Lithuania & Poland & Romania & Russia & Slovakia & Slovenia & Ukraine & Yugoslavia \\
\hline $\begin{array}{l}\text { No. } \\
\text { Observations }\end{array}$ & 935 & 15941 & 4271 & 5500 & 5783 & 4260 & 1864 & 774 & 9484 & 27335 & 2889 & 1221 & 297 & 14326 & 2227 \\
\hline $\begin{array}{l}\% \text { of Total Obs. } \\
\text { Across Countries }\end{array}$ & 0.01 & 0.16 & 0.04 & 0.06 & 0.06 & 0.04 & 0.02 & 0.01 & 0.10 & 0.28 & 0.03 & 0.01 & 0.00 & 0.15 & 0.02 \\
\hline $\begin{array}{l}\text { Total No. } \\
\text { Employees }\end{array}$ & 148116 & 1341327 & 587482 & 1472955 & 266252 & 831761 & 275167 & 150566 & 3220987 & 3020744 & 2649311 & 648695 & 80267 & 6509729 & 801772 \\
\hline $\begin{array}{l}\text { Employees } \\
\text { (median) }\end{array}$ & 104 & 25 & 29 & 100 & 21 & 50 & 55 & 49 & 133 & 24 & 257 & 150 & 165 & 221 & 128 \\
\hline Sales (U\$S) & 498883 & 206929 & 1693721 & 3014240 & 430033 & 2573242 & . & 1823899 & 5849727 & 283355 & $\cdot$ & 1898734 & 37506108 & 571973 & 2155926 \\
\hline Assets (U\$S) & 1248354 & 148662 & 1570135 & 2433507 & 196529 & 1309981 & 861991 & 1127647 & 4402955 & 139144 & 1839160 & 3233579 & 10481985 & 1568198 & 4508002 \\
\hline Age & 17 & 8 & 9 & 6 & 6 & 6 & 6 & 5 & 8 & 6 & 6 & 6 & 9 & 5 & 9 \\
\hline $\begin{array}{l}\text { Liabilities / } \\
\text { Equity }\end{array}$ & 0.37 & 0.71 & 2.21 & 1.12 & 1.40 & 1.29 & 1.41 & 1.08 & 1.08 & 1.58 & 0.67 & 1.14 & 0.77 & 0.29 & 0.51 \\
\hline Debt / Equity & 0.36 & 0.63 & 1.65 & 1.04 & 1.37 & 1.08 & 1.23 & 1.04 & 1.02 & 1.47 & 0.66 & 1.06 & 0.68 & 0.27 & 0.50 \\
\hline $\begin{array}{l}\text { Short-Term } \\
\text { Debt/ Equity }\end{array}$ & 0.31 & 0.58 & 1.65 & 0.76 & 1.11 & 1.07 & 0.98 & 0.88 & 0.90 & 1.39 & 0.62 & 0.83 & 0.68 & 0.22 & 0.42 \\
\hline $\begin{array}{l}\text { Acct Pay / } \\
\text { Equity }\end{array}$ & 0.04 & 0.04 & . & 0.02 & 0.22 & 0.97 & 0.17 & 0.12 & 0.22 & 0.52 & 0.00 & 0.04 & . & 0.11 & 0.05 \\
\hline $\begin{array}{l}\text { Short-Term / } \\
\text { Total Debt }\end{array}$ & 1.00 & 1.00 & 0.95 & 1.00 & 1.00 & 1.00 & 1.00 & 1.00 & 1.00 & 1.00 & 1.00 & 1.00 & 0.94 & 0.99 & 1.00 \\
\hline Current Ratio & 1.06 & 1.14 & 1.08 & 1.32 & 1.06 & 1.21 & 1.24 & 1.25 & 1.13 & 0.95 & 1.30 & 1.12 & 1.24 & 1.24 & 1.45 \\
\hline Cash Ratio & 0.02 & 0.13 & 0.04 & 0.16 & 0.11 & 0.12 & 0.08 & 0.07 & 0.08 & 0.07 & 0.05 & 0.10 & 0.04 & 0.01 & 0.03 \\
\hline $\begin{array}{l}\text { Fixed Assets / } \\
\text { Total Assets }\end{array}$ & 0.75 & 0.45 & 0.39 & 0.44 & 0.44 & 0.38 & 0.41 & 0.39 & 0.44 & 0.39 & 0.46 & 0.52 & 0.53 & 0.73 & 0.54 \\
\hline ROE & 0.01 & 0.05 & 0.10 & 0.05 & 0.08 & 0.16 & 0.14 & 0.13 & 0.07 & 0.19 & 0.00 & 0.01 & 0.04 & -0.01 & 0.00 \\
\hline ROA & 0.02 & 0.03 & 0.05 & 0.06 & 0.04 & 0.08 & 0.09 & 0.08 & 0.08 & 0.09 & 0.05 & 0.05 & 0.01 & 0.01 & 0.02 \\
\hline $\begin{array}{l}\text { 1-Yr Sales } \\
\text { Growth }\end{array}$ & . & -2.50 & -6.85 & -6.62 & -6.03 & 2.62 & . & . & -5.86 & -16.49 & . & -14.38 & . & -99.15 & -0.14 \\
\hline Agriculture $\%$ & 0.10 & 0.14 & 0.04 & 0.06 & 0.11 & 0.06 & 0.02 & 0.02 & 0.01 & 0.12 & 0.03 & 0.07 & 0.02 & 0.30 & 0.07 \\
\hline Industry $\%$ & 0.48 & 0.42 & 0.41 & 0.39 & 0.36 & 0.63 & 0.35 & 0.41 & 0.52 & 0.56 & 0.51 & 0.40 & 0.56 & 0.38 & 0.51 \\
\hline Service $\%$ & 0.38 & 0.42 & 0.50 & 0.50 & 0.46 & 0.30 & 0.58 & 0.55 & 0.40 & 0.32 & 0.36 & 0.45 & 0.38 & 0.26 & 0.38 \\
\hline
\end{tabular}




\section{Table 3: Median Summary Statistics, All Countries, All Firms, by Size and Age, 1999}

Sample includes all nonfinancial, private, and publicly traded firms with more than 10 employees. Current Ratio equals the ratio of current assets to current liabilities. Cash Ratio equals the ratio of cash to current liabilities. ROE equals the ratio of net income to equity. ROA equals the ratio of EBIT to total assets.

\begin{tabular}{|c|c|c|c|c|c|c|}
\hline All Firms & All firms & Employees $<=250$ & Employees > 250 & Firm Age 0-3 & Firm Age 3-10 & Firm Age $>10$ \\
\hline No. Observations & 97,107 & 79,723 & 16,917 & 13,206 & 47,863 & 9,367 \\
\hline$\%$ of Total Firms & . & $82.10 \%$ & $17.42 \%$ & $13.60 \%$ & $49.29 \%$ & $9.65 \%$ \\
\hline Total No. Employees & $22,005,131$ & $5,277,815$ & $16,610,566$ & $2,869,021$ & $8,850,285$ & $6,028,548$ \\
\hline Employees (median) & 55 & 35 & 478 & 50 & 44 & 260 \\
\hline Sales (U\$S) & 618,888 & 457,712 & $3,492,729$ & 634,865 & 730,255 & $2,774,792$ \\
\hline Assets (U\$S) & 591,525 & 353,173 & $4,346,968$ & 494,296 & 505,993 & $4,080,677$ \\
\hline Age & 6 & 6 & 8 & 2 & 7 & 42 \\
\hline Liabilities / Equity & 0.92 & 1.08 & 0.51 & 1.26 & 1.29 & 0.49 \\
\hline Debt / Equity & 0.84 & 0.98 & 0.47 & 1.17 & 1.19 & 0.44 \\
\hline Short-Term Debt/Equity & 0.75 & 0.88 & 0.41 & 1.02 & 1.06 & 0.39 \\
\hline Acct Pay / Equity & 0.16 & 0.18 & 0.10 & 0.20 & 0.26 & 0.10 \\
\hline Short-Term/Total Debt & 1.00 & 1.00 & 1.00 & 1.00 & 1.00 & 1.00 \\
\hline Current Ratio & 1.09 & 1.07 & 1.21 & 1.00 & 1.07 & 1.28 \\
\hline Cash Ratio & 0.07 & 0.08 & 0.04 & 0.07 & 0.08 & 0.04 \\
\hline Fixed Assets / Total Assets & 0.47 & 0.43 & 0.62 & 0.40 & 0.42 & 0.61 \\
\hline ROE & 0.06 & 0.09 & 0.00 & 0.10 & 0.10 & 0.00 \\
\hline ROA & 0.05 & 0.06 & 0.03 & 0.04 & 0.08 & 0.02 \\
\hline 1-Yr Sales Growth & -8.35 & -8.14 & -9.40 & 8.73 & -11.55 & -10.52 \\
\hline Agriculture \% & 0.11 & 0.11 & 0.14 & 0.11 & 0.09 & 0.09 \\
\hline Industry $\%$ & 0.47 & 0.45 & 0.57 & 0.45 & 0.50 & 0.59 \\
\hline Service \% & 0.38 & 0.41 & 0.24 & 0.40 & 0.38 & 0.26 \\
\hline
\end{tabular}




\section{Table 4a: Median Summary Statistics, by Age, 1999}

Sample includes all nonfinancial, private, and publicly traded firms with more than 10 employees and less than 3 years since incorporation.. Current Ratio equals the ratio of current assets to current liabilities. Cash Ratio equals the ratio of cash to current liabilities. $R O E$ equals the ratio of net income to equity. ROA equals the ratio of EBIT to total assets.

\begin{tabular}{|c|c|c|c|c|c|c|c|c|c|c|c|c|c|c|c|}
\hline $\begin{array}{l}\text { Firm Age } \\
0-3\end{array}$ & $\begin{array}{c}\text { Bosnia- } \\
\text { Herzegovina }\end{array}$ & Bulgaria & Croatia & $\begin{array}{c}\text { Czech } \\
\text { Republic }\end{array}$ & Estonia & Hungary & Latvia & Lithuania & Poland & Romania & Russia & Slovakia & Slovenia & Ukraine & Yugoslavia \\
\hline No. Observations & 89 & 118 & 216 & 903 & 1,306 & 706 & 349 & 194 & 1,254 & 4,868 & 598 & 284 & 22 & 2,146 & 153 \\
\hline $\begin{array}{l}\% \text { of Total } \\
\text { Country Obs. }\end{array}$ & $10 \%$ & $1 \%$ & $5 \%$ & $16 \%$ & $23 \%$ & $17 \%$ & $19 \%$ & $25 \%$ & $13 \%$ & $18 \%$ & $21 \%$ & $23 \%$ & $7 \%$ & $15 \%$ & $7 \%$ \\
\hline $\begin{array}{l}\text { Total No. } \\
\text { Employees }\end{array}$ & 3,044 & 13,266 & 51,625 & 151,270 & 47,362 & 61,552 & 32,205 & 17,538 & 244,774 & 571,564 & 272,045 & 106,175 & 3,488 & $1,239,160$ & 53,953 \\
\hline $\begin{array}{l}\% \text { of Total } \\
\text { Country Emp. }\end{array}$ & $2 \%$ & $1 \%$ & $9 \%$ & $10 \%$ & $18 \%$ & $7 \%$ & $12 \%$ & $12 \%$ & $8 \%$ & $19 \%$ & $10 \%$ & $16 \%$ & $4 \%$ & $19 \%$ & $7 \%$ \\
\hline $\begin{array}{l}\% \text { SMEs (less } \\
\text { than } 250 \text { Emp.) }\end{array}$ & 1.00 & 0.90 & 0.86 & 0.98 & 0.87 & 0.92 & 0.94 & 0.92 & 0.82 & 0.94 & 0.63 & 0.91 & 0.71 & 0.41 & 0.90 \\
\hline $\begin{array}{l}\text { Employees } \\
\text { (median) }\end{array}$ & 18 & 32 & 100 & 100 & 19 & 32 & 32 & 25 & 86 & 22 & 186 & 100 & 159 & 285 & 51 \\
\hline Sales (U\$S) & 410,144 & 718,804 & $3,201,993$ & $2,167,577$ & 331,076 & $1,710,062$ & . & 862,048 & $4,652,760$ & 205,877 & . & $1,385,350$ & . & 904,673 & $1,267,368$ \\
\hline Assets (U\$S) & 362,486 & 479,747 & $3,120,587$ & $1,454,154$ & 130,036 & 774,971 & 729,064 & 434,366 & $3,990,060$ & 106,396 & 860,603 & $2,175,891$ & $7,265,912$ & $2,061,571$ & $1,731,838$ \\
\hline Age & 2 & 2 & 2 & 2 & 2 & 2 & 2 & 2 & 2 & 2 & 2 & 2 & 2 & 2 & 2 \\
\hline $\begin{array}{l}\text { Liabilities / } \\
\text { Equity }\end{array}$ & 1.66 & 1.98 & 3.71 & 1.8 & 2.25 & 1.82 & 2.45 & 1.19 & 1.34 & 1.68 & 1.08 & 1.25 & 2.65 & 0.33 & 1.27 \\
\hline Debt / Equity & 1.52 & 1.36 & 2.9 & 1.73 & 2.2 & 1.49 & 2.2 & 1.17 & 1.29 & 1.55 & 1.08 & 1.23 & 1.32 & 0.31 & 1.24 \\
\hline $\begin{array}{l}\text { Short-Term Debt } \\
\text { / Equity }\end{array}$ & 1.4 & 1.08 & 2.9 & 1.26 & 1.69 & 1.47 & 1.64 & 1.05 & 1.16 & 1.49 & 0.98 & 0.91 & 1.32 & 0.27 & 1.23 \\
\hline Acct Pay / Equity & 0.08 & 0.05 & . & 0.02 & 0.32 & 1.36 & 0.17 & 0.15 & 0.23 & 0.52 & 0.00 & 0.04 & . & 0.12 & 0.12 \\
\hline $\begin{array}{l}\text { Short-Term / } \\
\text { Total Debt }\end{array}$ & 1.00 & 1.00 & 1.00 & 1.00 & 1.00 & 1.00 & 1.00 & 1.00 & 1.00 & 1.00 & 1.00 & 1.00 & 1.00 & 0.95 & 1.00 \\
\hline Current Ratio & 1.04 & 1.00 & 1.01 & 1.11 & 0.98 & 1.11 & 1.05 & 1.21 & 1.07 & 0.89 & 1.23 & 0.99 & 1.13 & 1.08 & 1.16 \\
\hline Cash Ratio & 0.03 & 0.11 & 0.04 & 0.14 & 0.11 & 0.12 & 0.07 & 0.09 & 0.08 & 0.07 & 0.06 & 0.08 & 0.03 & 0.01 & 0.03 \\
\hline $\begin{array}{l}\text { Fixed Assets / } \\
\text { Total Assets }\end{array}$ & 0.31 & 0.34 & 0.31 & 0.33 & 0.38 & 0.35 & 0.39 & 0.27 & 0.4 & 0.34 & 0.31 & 0.56 & 0.48 & 0.7 & 0.27 \\
\hline ROE & 0.1 & 0.15 & 0.07 & 0.06 & 0.18 & 0.2 & 0.2 & 0.2 & 0.1 & 0.4 & 0.00 & 0.01 & 0.07 & -0.02 & 0.01 \\
\hline $\mathrm{ROA}$ & 0.07 & 0.07 & 0.02 & 0.04 & 0.03 & 0.07 & 0.07 & 0.07 & 0.06 & 0.05 & 0.05 & 0.03 & 0.01 & 0.01 & 0.03 \\
\hline $\begin{array}{l}\text { 1-Yr Sales } \\
\text { Growth }\end{array}$ & . & 50.27 & 1.68 & 2.45 & 7.71 & 10.49 & . & 5.19 & 9.03 & 12.25 & . & -7.91 & . & . & 45.25 \\
\hline Agriculture $\%$ & 0.04 & 0.00 & 0.08 & 0.05 & 0.14 & 0.03 & 0.01 & 0.01 & 0.01 & 0.14 & 0.04 & 0.02 & 0.00 & 0.19 & 0.03 \\
\hline Industry $\%$ & 0.39 & 0.46 & 0.44 & 0.29 & 0.33 & 0.6 & 0.35 & 0.3 & 0.44 & 0.52 & 0.47 & 0.29 & 0.64 & 0.44 & 0.43 \\
\hline Service $\%$ & 0.54 & 0.54 & 0.46 & 0.62 & 0.44 & 0.35 & 0.6 & 0.69 & 0.46 & 0.33 & 0.42 & 0.6 & 0.36 & 0.32 & 0.46 \\
\hline
\end{tabular}




\section{Table 4b: Median Summary Statistics, by Age, 1999}

Sample includes all nonfinancial, private, and publicly traded firms with more than 10 employees and between 4 and 10 years since incorporation. Current Ratio equals the ratio of current assets to current liabilities. Cash Ratio equals the ratio of cash to current liabilities. $R O E$ equals the ratio of net income to equity. ROA equals the ratio of EBIT to total assets.

\begin{tabular}{|c|c|c|c|c|c|c|c|c|c|c|c|c|c|c|c|}
\hline $\begin{array}{l}\text { Firm Age } \\
4-10\end{array}$ & $\begin{array}{c}\text { Bosnia- } \\
\text { Herzegovina }\end{array}$ & Bulgaria & Croatia & $\begin{array}{c}\text { Czech } \\
\text { Republic }\end{array}$ & Estonia & Hungary & Latvia & Lithuania & Poland & Romania & Russia & Slovakia & Slovenia & Ukraine & Yugoslavia \\
\hline $\begin{array}{l}\text { No. } \\
\text { Observations }\end{array}$ & 255 & 994 & 866 & 4,007 & 4,165 & 3,087 & 1,502 & 561 & 4,722 & 22,324 & 1,830 & 843 & 220 & 1,387 & 1,100 \\
\hline $\begin{array}{l}\% \text { of Total } \\
\text { Country Obs. }\end{array}$ & $27 \%$ & $6 \%$ & $20 \%$ & $73 \%$ & $72 \%$ & $72 \%$ & $81 \%$ & $72 \%$ & $50 \%$ & $82 \%$ & $63 \%$ & $69 \%$ & $74 \%$ & $10 \%$ & $49 \%$ \\
\hline $\begin{array}{l}\text { Total No. } \\
\text { Employees }\end{array}$ & 27,024 & 166,183 & 144,327 & $1,107,965$ & 176,225 & 681,996 & 239,275 & 125,928 & $1,165,958$ & $2,248,700$ & $1,247,808$ & 484,720 & 58,397 & 761,965 & 213,814 \\
\hline $\begin{array}{l}\% \text { of Total } \\
\text { Country Emp. }\end{array}$ & $18 \%$ & $12 \%$ & $25 \%$ & $75 \%$ & $66 \%$ & $82 \%$ & $87 \%$ & $84 \%$ & $36 \%$ & $74 \%$ & $47 \%$ & $75 \%$ & $73 \%$ & $12 \%$ & $27 \%$ \\
\hline $\begin{array}{l}\% \text { SMEs (less } \\
\text { than } 250 \text { Emp.) }\end{array}$ & 0.94 & 0.90 & 0.79 & 0.98 & 0.92 & 0.84 & 0.81 & 0.87 & 0.82 & 0.93 & 0.52 & 0.70 & 0.69 & 0.37 & 0.84 \\
\hline $\begin{array}{l}\text { Employees } \\
\text { (median) }\end{array}$ & 42 & 105 & 53 & 100 & 22 & 60 & 60 & 64 & 102 & 24 & 239 & 150 & 160 & 289 & 107 \\
\hline Sales (U\$S) & 487,020 & 707,369 & $3,091,904$ & $3,236,894$ & 439,453 & $2,844,373$ & . & $2,247,496$ & $6,084,029$ & 295,806 & . & $2,266,866$ & $41,710,687$ & 678,172 & $1,711,733$ \\
\hline Assets (U\$S) & 875,347 & 512,420 & $2,811,480$ & $2,517,729$ & 206,522 & $1,475,582$ & 885,494 & $1,342,542$ & $4,130,465$ & 144,119 & $1,660,626$ & $3,299,847$ & $10,564,802$ & $2,213,080$ & $3,027,559$ \\
\hline Age & 7 & 7 & 8 & 7 & 7 & 7 & 6 & 6 & 7 & 7 & 6 & 7 & 9 & 5 & 8 \\
\hline $\begin{array}{l}\text { Liabilities / } \\
\text { Equity }\end{array}$ & 0.6 & 1.07 & 3.19 & 1.14 & 1.33 & 1.21 & 1.29 & 1.05 & 1.44 & 1.58 & 0.63 & 1.23 & 0.82 & 0.27 & 0.68 \\
\hline Debt / Equity & 0.58 & 0.93 & 2.55 & 1.06 & 1.3 & 1 & 1.15 & 1.03 & 1.38 & 1.46 & 0.63 & 1.17 & 0.69 & 0.25 & 0.66 \\
\hline $\begin{array}{l}\text { Short-Term } \\
\text { Debt/ Equity }\end{array}$ & 0.47 & 0.81 & 2.55 & 0.77 & 1.05 & 0.99 & 0.91 & 0.84 & 1.2 & 1.37 & 0.6 & 0.9 & 0.69 & 0.21 & 0.58 \\
\hline $\begin{array}{l}\text { Acct Pay / } \\
\text { Equity }\end{array}$ & 0.06 & 0.06 & . & 0.02 & 0.21 & 0.91 & 0.17 & 0.11 & 0.23 & 0.52 & 0.00 & 0.04 & . & 0.1 & 0.06 \\
\hline $\begin{array}{l}\text { Short -Term / } \\
\text { Total Debt }\end{array}$ & 1.00 & 1.00 & 1.00 & 0.94 & 1.00 & 1.00 & 1.00 & 1.00 & 1.00 & 1.00 & 1.00 & 1.00 & 1.00 & 0.94 & 1.00 \\
\hline Current Ratio & 1.07 & 1.09 & 1.02 & 1.36 & 1.1 & 1.24 & 1.28 & 1.27 & 1.1 & 0.97 & 1.31 & 1.14 & 1.22 & 1.23 & 1.32 \\
\hline Cash Ratio & 0.02 & 0.09 & 0.03 & 0.15 & 0.1 & 0.12 & 0.09 & 0.07 & 0.08 & 0.07 & 0.06 & 0.1 & 0.03 & 0.01 & 0.03 \\
\hline $\begin{array}{l}\text { Fixed Assets / } \\
\text { Total Assets }\end{array}$ & 0.66 & 0.44 & 0.36 & 0.44 & 0.44 & 0.38 & 0.42 & 0.41 & 0.37 & 0.4 & 0.47 & 0.49 & 0.53 & 0.71 & 0.48 \\
\hline ROE & 0.02 & 0.04 & 0.11 & 0.06 & 0.06 & 0.16 & 0.13 & 0.12 & 0.15 & 0.17 & 0.00 & 0.01 & 0.04 & 0.00 & 0.01 \\
\hline ROA & 0.02 & 0.04 & 0.05 & 0.07 & 0.04 & 0.08 & 0.1 & 0.09 & 0.11 & 0.1 & 0.06 & 0.06 & 0.01 & 0.01 & 0.02 \\
\hline $\begin{array}{l}\text { 1-Yr Sales } \\
\text { Growth }\end{array}$ & . & -1.01 & -7.37 & -7.37 & -7.8 & 0.54 & . & -3.41 & -4.46 & -18.58 & . & -14.8 & . & . & 3.11 \\
\hline Agriculture $\%$ & 0.11 & 0.12 & 0.03 & 0.05 & 0.11 & 0.06 & 0.03 & 0.03 & 0.02 & 0.11 & 0.02 & 0.05 & 0.01 & 0.2 & 0.06 \\
\hline Industry $\%$ & 0.37 & 0.47 & 0.38 & 0.42 & 0.37 & 0.64 & 0.35 & 0.44 & 0.47 & 0.56 & 0.47 & 0.46 & 0.51 & 0.36 & 0.46 \\
\hline Service $\%$ & 0.48 & 0.4 & 0.57 & 0.46 & 0.46 & 0.28 & 0.58 & 0.51 & 0.48 & 0.32 & 0.39 & 0.42 & 0.42 & 0.38 & 0.45 \\
\hline
\end{tabular}




\section{Table 4c: Median Summary Statistics, by Age, 1999}

Sample includes all nonfinancial, private, and publicly traded firms with more than 10 employees and more than 10 years since incorporation.. Current Ratio equals the ratio of current assets to current liabilities. Cash Ratio equals the ratio of cash to current liabilities. $R O E$ equals the ratio of net income to equity. ROA equals the ratio of EBIT to total assets.

\begin{tabular}{|c|c|c|c|c|c|c|c|c|c|c|c|c|c|c|c|}
\hline $\begin{array}{l}\text { Firm Age } \\
>10\end{array}$ & $\begin{array}{c}\text { Bosnia- } \\
\text { Herzegovina }\end{array}$ & Bulgaria & Croatia & $\begin{array}{c}\text { Czech } \\
\text { Republic }\end{array}$ & Estonia & Hungary & Latvia & Lithuania & Poland & Romania & Russia & Slovakia & Slovenia & Ukraine & Yugoslavia \\
\hline $\begin{array}{l}\text { No. } \\
\text { Observations }\end{array}$ & 591 & 678 & 923 & 297 & 311 & 37 & 4 & . & 3,138 & 1 & 400 & 93 & 52 & 1,868 & 974 \\
\hline $\begin{array}{l}\% \text { of Total } \\
\text { Country Obs. }\end{array}$ & $63 \%$ & $4 \%$ & $22 \%$ & $5 \%$ & $5 \%$ & $1 \%$ & $0 \%$ & . & $33 \%$ & $0 \%$ & $14 \%$ & $8 \%$ & $18 \%$ & $13 \%$ & $44 \%$ \\
\hline $\begin{array}{l}\text { Total No. } \\
\text { Employees }\end{array}$ & 118,048 & 336,653 & 330,216 & 98,030 & 42,646 & 28,500 & 208 & . & $1,685,807$ & 4,247 & $1,070,802$ & 57,700 & 17,575 & $1,704,111$ & 534,005 \\
\hline $\begin{array}{l}\% \text { of Total } \\
\text { Country Emp. }\end{array}$ & $80 \%$ & $25 \%$ & $56 \%$ & $7 \%$ & $16 \%$ & $3 \%$ & $0 \%$ & . & $52 \%$ & $0 \%$ & $40 \%$ & $9 \%$ & $22 \%$ & $26 \%$ & $67 \%$ \\
\hline $\begin{array}{l}\% \text { SMEs (less } \\
\text { than } 250 \text { Emp.) }\end{array}$ & 0.82 & 0.62 & 0.64 & 0.89 & 0.64 & 0.65 & . & 1.00 & 0.52 & . & 0.17 & 0.56 & 0.54 & 0.07 & 0.55 \\
\hline $\begin{array}{l}\text { Employees } \\
\text { (median) }\end{array}$ & 110 & 179 & 180 & 200 & 53 & 113 & 16 & . & 234 & 4,247 & 872 & 200 & 214 & 414 & 212 \\
\hline Sales (U\$S) & 510,557 & $1,045,534$ & $4,097,114$ & $3,129,733$ & 932,040 & $7,499,414$ & . & . & $5,993,283$ & $1,948,804$ & . & $1,644,810$ & $33,301,528$ & 894,287 & $3,095,004$ \\
\hline Assets (U\$S) & $1,733,893$ & $1,198,824$ & $10,008,092$ & $5,624,421$ & 649,971 & $4,302,191$ & 173,742 & . & $4,754,723$ & $3,123,046$ & 7,297,703 & $6,648,650$ & $13,070,532$ & $2,931,502$ & $7,403,764$ \\
\hline Age & 25 & 39 & 45 & 22 & 36 & 12 & 99 & . & 45 & 1,999 & 46 & 23 & 24 & 52 & 42 \\
\hline $\begin{array}{l}\text { Liabilities / } \\
\text { Equity }\end{array}$ & 0.25 & 0.55 & 0.72 & 0.48 & 0.85 & 1.07 & 5.25 & . & 0.76 & -1.81 & 0.57 & 0.47 & 0.49 & 0.25 & 0.36 \\
\hline Debt / Equity & 0.25 & 0.4 & 0.49 & 0.45 & 0.84 & 1.07 & 5.19 & . & 0.72 & -0.35 & 0.57 & 0.44 & 0.4 & 0.24 & 0.36 \\
\hline $\begin{array}{l}\text { Short-Term } \\
\text { Debt/ Equity }\end{array}$ & 0.23 & 0.37 & 0.49 & 0.26 & 0.64 & 1.07 & 4.21 & . & 0.65 & -0.33 & 0.54 & 0.33 & 0.4 & 0.2 & 0.3 \\
\hline $\begin{array}{l}\text { Acct Pay / } \\
\text { Equity }\end{array}$ & 0.03 & 0.04 & . & 0.01 & 0.15 & 0.86 & 0.44 & . & 0.21 & -0.17 & 0.00 & 0.02 & . & 0.1 & 0.05 \\
\hline $\begin{array}{l}\text { Short -Term / } \\
\text { Total Debt }\end{array}$ & 1.00 & 1.00 & 1.00 & 0.69 & 0.94 & 1.00 & 1.00 & . & 0.97 & 1.00 & 0.95 & 1.00 & 1.00 & 0.82 & 0.95 \\
\hline Current Ratio & 1.06 & 1.28 & 1.18 & 1.54 & 1.16 & 1.35 & 1.21 & . & 1.2 & 1.36 & 1.32 & 1.51 & 1.51 & 1.32 & 1.69 \\
\hline Cash Ratio & 0.02 & 0.09 & 0.03 & 0.27 & 0.13 & 0.08 & 0.09 & . & 0.08 & 0.53 & 0.02 & 0.14 & 0.04 & 0.01 & 0.03 \\
\hline $\begin{array}{l}\text { Fixed Assets / } \\
\text { Total Assets }\end{array}$ & 0.8 & 0.58 & 0.61 & 0.63 & 0.59 & 0.46 & 0.31 & . & 0.51 & 0.45 & 0.51 & 0.65 & 0.54 & 0.76 & 0.59 \\
\hline ROE & 0.01 & 0.01 & 0.00 & 0.00 & 0.03 & 0.15 & 0.15 & . & 0.03 & 0.04 & -0.42 & 0.00 & 0.04 & -0.02 & 0.00 \\
\hline ROA & 0.01 & 0.01 & 0.01 & 0.02 & 0.05 & 0.07 & 0.06 & . & 0.05 & 0.37 & -0.13 & 0.02 & 0.01 & 0.01 & 0.01 \\
\hline $\begin{array}{l}\text { 1-Yr Sales } \\
\text { Growth }\end{array}$ & . & -15.69 & -13.95 & -8.77 & -7.05 & -1.71 & . & . & -9.89 & -39.48 & . & -17.28 & . & -99.15 & -3.53 \\
\hline Agriculture $\%$ & 0.11 & 0.03 & 0.04 & 0.17 & 0.07 & 0.06 & 0.00 & . & 0.01 & 0.00 & 0.02 & 0.33 & 0.04 & 0.26 & 0.09 \\
\hline Industry $\%$ & 0.54 & 0.71 & 0.58 & 0.35 & 0.38 & 0.65 & 0.00 & . & 0.64 & 1.00 & 0.79 & 0.28 & 0.73 & 0.54 & 0.59 \\
\hline Service $\%$ & 0.31 & 0.23 & 0.35 & 0.46 & 0.49 & 0.16 & 0.5 & . & 0.27 & 0.00 & 0.14 & 0.32 & 0.21 & 0.15 & 0.29 \\
\hline
\end{tabular}




\section{Table 5a: Median Summary Statistics, by Employment, 1999}

Sample includes all nonfinancial, private, and publicly traded firms with more than 10 employees and less than 250 employees. Current Ratio equals the ratio of current assets to current liabilities. Cash Ratio equals the ratio of cash to current liabilities. ROE equals the ratio of net income to equity. ROA equals the ratio of EBIT to total assets.

\begin{tabular}{|c|c|c|c|c|c|c|c|c|c|c|c|c|c|c|c|}
\hline $\begin{array}{l}\text { Employees } \\
<=250\end{array}$ & $\begin{array}{c}\text { Bosnia- } \\
\text { Herzegovina }\end{array}$ & Bulgaria & Croatia & $\begin{array}{c}\text { Czech } \\
\text { Republic }\end{array}$ & Estonia & Hungary & Latvia & Lithuania & Poland & Romania & Russia & Slovakia & Slovenia & Ukraine & Yugoslavia \\
\hline $\begin{array}{l}\text { No. } \\
\text { Observations }\end{array}$ & 812 & 15,123 & 3,838 & 4,301 & 5,656 & 3,614 & 1,634 & 638 & 6,746 & 25,535 & 1,415 & 831 & 202 & 7,783 & 1,595 \\
\hline $\begin{array}{l}\% \text { of Total } \\
\text { Country Obs. }\end{array}$ & $87 \%$ & $95 \%$ & $90 \%$ & $78 \%$ & $98 \%$ & $85 \%$ & $88 \%$ & $82 \%$ & $71 \%$ & $93 \%$ & $49 \%$ & $70 \%$ & $68 \%$ & $54 \%$ & $72 \%$ \\
\hline $\begin{array}{l}\text { Total No. } \\
\text { Employees }\end{array}$ & 69,055 & 672,585 & 200,833 & 390,455 & 189,921 & 228,882 & 111,447 & 39,062 & 685,245 & $1,025,099$ & 209,703 & 73,945 & 24,757 & $1,193,852$ & 162,974 \\
\hline $\begin{array}{l}\% \text { of Total } \\
\text { Country Emp. }\end{array}$ & $47 \%$ & $50 \%$ & $34 \%$ & $27 \%$ & $71 \%$ & $28 \%$ & $41 \%$ & $26 \%$ & $21 \%$ & $34 \%$ & $8 \%$ & $11 \%$ & $31 \%$ & $18 \%$ & $20 \%$ \\
\hline $\begin{array}{l}\% \text { new firms } \\
\text { (age } 0-3 \text { ) }\end{array}$ & 0.11 & 0.07 & 0.19 & 0.23 & 0.12 & 0.20 & 0.29 & 0.20 & 0.16 & 0.18 & 0.27 & 0.10 & 0.24 & 0.56 & 0.09 \\
\hline $\begin{array}{l}\text { Emplo yees } \\
\text { (median) }\end{array}$ & 101 & 24 & 25 & 50 & 21 & 40 & 42 & 37 & 92 & 22 & 139 & 100 & 119 & 147 & 103 \\
\hline Sales (U\$S) & 419,541 & 190,592 & $1,499,063$ & $2,271,282$ & 411,062 & $2,046,170$ & . & $1,374,646$ & $4,411,022$ & 252,177 & & $1,098,281$ & $33,301,528$ & 361,559 & $1,392,421$ \\
\hline Assets (U\$S) & 988,295 & 136,682 & $1,276,917$ & $1,746,003$ & 189,497 & $1,026,537$ & 733,566 & 801,686 & $3,129,106$ & 121,310 & 579,693 & $1,837,012$ & $8,009,930$ & 929,440 & $2,632,167$ \\
\hline Age & 14 & 8 & 9 & 6 & 6 & 6 & 6 & 5 & 8 & 6 & 6 & 6 & 9 & 3 & 9 \\
\hline $\begin{array}{l}\text { Liabilities / } \\
\text { Equity }\end{array}$ & 0.4 & 0.72 & 2.57 & 1.2 & 1.42 & 1.36 & 1.6 & 1.22 & 1.3 & 1.68 & 0.78 & 1.23 & 1.02 & 0.3 & 0.56 \\
\hline Debt / Equity & 0.39 & 0.63 & 1.99 & 1.11 & 1.39 & 1.13 & 1.37 & 1.21 & 1.23 & 1.55 & 0.78 & 1.17 & 0.79 & 0.28 & 0.54 \\
\hline $\begin{array}{l}\text { Short -Term } \\
\text { Debt / Equity }\end{array}$ & 0.23 & 0.37 & 0.49 & 0.26 & 0.64 & 1.07 & 4.21 & . & 0.65 & -0.33 & 0.54 & 0.33 & 0.4 & 0.2 & 0.3 \\
\hline $\begin{array}{l}\text { Acct Pay / } \\
\text { Equity }\end{array}$ & 0.04 & 0.04 & . & 0.02 & 0.22 & 1.03 & 0.17 & 0.13 & 0.22 & 0.55 & 0.00 & 0.04 & . & 0.12 & 0.05 \\
\hline $\begin{array}{l}\text { Short -Term / } \\
\text { Total Debt }\end{array}$ & 1.00 & 1.00 & 0.97 & 1.00 & 1.00 & 1.00 & 1.00 & 1.00 & 1.00 & 1.00 & 1.00 & 1.00 & 0.96 & 1.00 & 1.00 \\
\hline Current Ratio & 1.04 & 1.14 & 1.07 & 1.33 & 1.06 & 1.22 & 1.23 & 1.24 & 1.14 & 0.94 & 1.28 & 1.13 & 1.22 & 1.25 & 1.37 \\
\hline Cash Ratio & 0.02 & 0.13 & 0.04 & 0.17 & 0.11 & 0.12 & 0.08 & 0.08 & 0.08 & 0.07 & 0.08 & 0.12 & 0.04 & 0.01 & 0.03 \\
\hline $\begin{array}{l}\text { Fixed Assets / } \\
\text { Total Assets }\end{array}$ & 0.74 & 0.45 & 0.36 & 0.4 & 0.43 & 0.36 & 0.38 & 0.35 & 0.38 & 0.38 & 0.39 & 0.48 & 0.5 & 0.72 & 0.51 \\
\hline ROE & 0.01 & 0.05 & 0.12 & 0.06 & 0.08 & 0.18 & 0.16 & 0.14 & 0.11 & 0.21 & 0.00 & 0.01 & 0.04 & 0.00 & 0.01 \\
\hline ROA & 0.02 & 0.03 & 0.05 & 0.06 & 0.04 & 0.08 & 0.1 & 0.08 & 0.09 & 0.09 & 0.07 & 0.04 & 0.01 & 0.02 & 0.02 \\
\hline $\begin{array}{l}\text { 1-Yr Sales } \\
\text { Growth }\end{array}$ & . & -2.01 & -6.39 & -7.06 & -6.13 & 3.36 & . & -0.02 & -5.57 & -15.83 & . & -15.59 & . & . & 2.8 \\
\hline Agriculture $\%$ & 0.11 & 0.15 & 0.04 & 0.06 & 0.12 & 0.05 & 0.02 & 0.02 & 0.02 & 0.12 & 0.01 & 0.08 & 0.02 & 0.27 & 0.07 \\
\hline Industry $\%$ & 0.45 & 0.4 & 0.39 & 0.33 & 0.36 & 0.6 & 0.33 & 0.33 & 0.48 & 0.55 & 0.4 & 0.29 & 0.46 & 0.35 & 0.45 \\
\hline Service $\%$ & 0.4 & 0.42 & 0.52 & 0.55 & 0.46 & 0.32 & 0.61 & 0.64 & 0.46 & 0.33 & 0.46 & 0.54 & 0.46 & 0.31 & 0.43 \\
\hline
\end{tabular}




\section{Table 5b: Median Summary Statistics, by Employment, 1999}

Sample includes all nonfinancial, private, and publicly traded firms with more than 250 employees. Current Ratio equals the ratio of current assets to current liabilities. Cash Ratio equals the ratio of cash to current liabilities. ROE equals the ratio of net income to equity. ROA equals the ratio of EBIT to total assets.

\begin{tabular}{|c|c|c|c|c|c|c|c|c|c|c|c|c|c|c|c|}
\hline $\begin{array}{l}\text { Employees } \\
>250\end{array}$ & $\begin{array}{c}\text { Bosnia- } \\
\text { Herzegovina }\end{array}$ & Bulgaria & Croatia & $\begin{array}{c}\text { Czech } \\
\text { Republic }\end{array}$ & Estonia & Hungary & Latvia & Lithuania & Poland & Romania & Russia & Slovakia & Slovenia & Ukraine & Yugoslavia \\
\hline $\begin{array}{l}\text { No. } \\
\text { Observations }\end{array}$ & 123 & 816 & 431 & 945 & 125 & 623 & 230 & 135 & 2,710 & 1,782 & 1,468 & 333 & 94 & 6,477 & 625 \\
\hline $\begin{array}{l}\% \text { of Total } \\
\text { Country Obs. }\end{array}$ & $13 \%$ & $5 \%$ & $10 \%$ & $17 \%$ & $2 \%$ & $15 \%$ & $12 \%$ & $17 \%$ & $29 \%$ & $7 \%$ & $51 \%$ & $27 \%$ & $32 \%$ & $45 \%$ & $28 \%$ \\
\hline $\begin{array}{l}\text { Total No. } \\
\text { Employees }\end{array}$ & 79,061 & 668,242 & 386,149 & $1,019,000$ & 75,831 & 597,129 & 163,720 & 111,254 & $2,528,742$ & $1,991,145$ & $2,438,108$ & 560,500 & 55,260 & $5,299,377$ & 637,048 \\
\hline $\begin{array}{l}\% \text { of Total } \\
\text { Country Emp. }\end{array}$ & $53 \%$ & $50 \%$ & $66 \%$ & $69 \%$ & $28 \%$ & $72 \%$ & $59 \%$ & $74 \%$ & $79 \%$ & $66 \%$ & $92 \%$ & $86 \%$ & $69 \%$ & $81 \%$ & $79 \%$ \\
\hline $\begin{array}{l}\% \text { new firms } \\
\text { (age } 0-3 \text { ) }\end{array}$ & 0.00 & 0.03 & 0.12 & 0.16 & 0.07 & 0.09 & 0.09 & 0.13 & 0.09 & 0.15 & 0.16 & 0.02 & 0.21 & 0.33 & 0.02 \\
\hline $\begin{array}{l}\text { Employees } \\
\text { (median) }\end{array}$ & 408 & 415 & 447 & 500 & 398 & 469 & 378 & 550 & 462 & 508 & 623 & 1,000 & 435 & 408 & 450 \\
\hline Sales (U\$S) & $2,329,992$ & $3,031,775$ & $11,476,363$ & $14,930,033$ & $2,367,463$ & $15,720,934$ & . & $7,553,918$ & $13,325,198$ & $2,140,980$ & . & $9,491,686$ & $41,710,687$ & 855,393 & $7,550,253$ \\
\hline Assets (U\$S) & $8,978,885$ & $3,492,463$ & $24,314,143$ & $13,658,035$ & $2,286,727$ & $12,221,789$ & $5,757,834$ & $6,435,367$ & $9,159,317$ & $1,850,142$ & $5,243,514$ & $13,549,870$ & $30,096,244$ & $2,856,619$ & $18,695,979$ \\
\hline Age & 29 & 33 & 44 & 7 & 7 & 6 & 6 & 6 & 24 & 8 & 6 & 6 & 9 & 6 & 34 \\
\hline $\begin{array}{l}\text { Liabilities / } \\
\text { Equity }\end{array}$ & 0.23 & 0.58 & 0.85 & 0.92 & 0.49 & 0.97 & 0.58 & 0.4 & 0.83 & 0.79 & 0.6 & 1.1 & 0.63 & 0.28 & 0.43 \\
\hline Debt / Equity & 0.22 & 0.48 & 0.56 & 0.86 & 0.46 & 0.87 & 0.53 & 0.4 & 0.8 & 0.72 & 0.6 & 1.01 & 0.55 & 0.26 & 0.43 \\
\hline $\begin{array}{l}\text { Short -Term } \\
\text { Debt / Equity }\end{array}$ & 0.21 & 0.41 & 0.56 & 0.62 & 0.37 & 0.84 & 0.42 & 0.34 & 0.72 & 0.66 & 0.56 & 0.82 & 0.55 & 0.21 & 0.34 \\
\hline $\begin{array}{l}\text { Acct Pay / } \\
\text { Equity }\end{array}$ & 0.03 & 0.04 & . & 0.02 & 0.1 & 0.71 & 0.12 & 0.07 & 0.22 & 0.27 & 0.00 & 0.04 & . & 0.11 & 0.06 \\
\hline $\begin{array}{l}\text { Short-Term / } \\
\text { Total Debt }\end{array}$ & 1.00 & 1.00 & 0.87 & 0.82 & 1.00 & 1.00 & 0.86 & 1.00 & 1.00 & 1.00 & 1.00 & 1.00 & 0.87 & 0.94 & 0.95 \\
\hline Current Ratio & 1.17 & 1.15 & 1.17 & 1.27 & 1.11 & 1.15 & 1.45 & 1.43 & 1.11 & 1.17 & 1.31 & 1.09 & 1.35 & 1.23 & 1.68 \\
\hline Cash Ratio & 0.02 & 0.07 & 0.03 & 0.1 & 0.11 & 0.09 & 0.11 & 0.05 & 0.08 & 0.07 & 0.03 & 0.07 & 0.03 & 0.01 & 0.03 \\
\hline $\begin{array}{l}\text { Fixed Assets / } \\
\text { Total Assets }\end{array}$ & 0.78 & 0.58 & 0.6 & 0.55 & 0.64 & 0.47 & 0.58 & 0.58 & 0.52 & 0.51 & 0.49 & 0.57 & 0.55 & 0.75 & 0.58 \\
\hline ROE & 0.00 & 0.02 & 0.00 & 0.03 & 0.02 & 0.06 & 0.04 & 0.04 & 0.04 & 0.03 & -0.02 & 0.01 & 0.04 & -0.02 & 0.00 \\
\hline ROA & 0.01 & 0.03 & 0.01 & 0.06 & 0.13 & 0.05 & 0.08 & 0.1 & 0.06 & 0.13 & 0.03 & 0.05 & 0.02 & 0.01 & 0.01 \\
\hline $\begin{array}{l}\text { 1-Yr Sales } \\
\text { Growth }\end{array}$ & . & -9.3 & -10.59 & -5.64 & 0.5 & -1.03 & . & 0.78 & -6.54 & -24.55 & . & -12.51 & . & -99.15 & -4.46 \\
\hline Agriculture $\%$ & 0.08 & 0.04 & 0.05 & 0.03 & 0.06 & 0.06 & 0.03 & 0.05 & 0.01 & 0.07 & 0.04 & 0.03 & 0.00 & 0.32 & 0.08 \\
\hline Industry $\%$ & 0.68 & 0.69 & 0.6 & 0.62 & 0.54 & 0.72 & 0.51 & 0.78 & 0.64 & 0.69 & 0.62 & 0.68 & 0.77 & 0.41 & 0.67 \\
\hline Service $\%$ & 0.22 & 0.25 & 0.32 & 0.3 & 0.36 & 0.2 & 0.39 & 0.16 & 0.26 & 0.22 & 0.27 & 0.25 & 0.21 & 0.22 & 0.24 \\
\hline
\end{tabular}




\section{Table 6: Summary Statistics of ECA Countries, 1999}

Private capital flows and 5-year growth rates of GDP are from IFS Statistics. The percentage of banking system's assets in banks that $50 \%$ or more government and foreign bank assets is from the Bank Regulation and Supervision Database (Barth, Caprio, and Levine, 2001). Rule of Law is an index of several indicators that measure the extent to which citizens have confidence in and abide by country rules. This includes the perception of the effectiveness of the judiciary and the enforceability of contracts (Kaufman and Kraay, 2001).

\begin{tabular}{|c|c|c|c|c|c|c|}
\hline $\begin{array}{l}\text { Country } \\
\text { Name }\end{array}$ & $\begin{array}{c}\text { Private } \\
\text { capital } \\
\text { flows }(\% \text { of } \\
\text { GDP })\end{array}$ & $\begin{array}{c}\text { Logged } \\
\text { GDP } \\
\text { Per Capita }\end{array}$ & $\begin{array}{c}\text { GDP 5-Yr } \\
\text { growth }\end{array}$ & $\begin{array}{l}\text { Government } \\
\text { Bank Assets }\end{array}$ & $\begin{array}{c}\text { Foreign } \\
\text { Bank } \\
\text { Assets }\end{array}$ & $\begin{array}{c}\text { Rule of } \\
\text { law }\end{array}$ \\
\hline $\begin{array}{l}\text { Bosnia } \\
\text { Bulgaria } \\
\text { Croatia } \\
\text { Czech Rep. } \\
\text { Estonia } \\
\text { Hungary } \\
\text { Latvia } \\
\text { Lithuania } \\
\text { Poland } \\
\text { Romania } \\
\text { Russia } \\
\text { Slovak Rep. } \\
\text { Slovenia } \\
\text { Ukraine } \\
\text { Yugoslavia }\end{array}$ & $\begin{array}{c}13.21 \\
17.23 \\
28.93 \\
26.33 \\
24.67 \\
23.28 \\
18.47 \\
11.44 \\
9.29 \\
11.12 \\
32.56 \\
10.80 \\
16.00 \\
.\end{array}$ & $\begin{array}{c}1479.49 \\
1413.71 \\
4968.81 \\
5156.75 \\
4110.26 \\
5135.82 \\
2398.29 \\
1976.98 \\
4060.57 \\
1434.69 \\
2255.07 \\
4075.41 \\
11159.94 \\
840.00 \\
1181.50\end{array}$ & $\begin{array}{r}32.64 \\
-1.68 \\
4.34 \\
1.58 \\
4.48 \\
3.29 \\
3.22 \\
3.30 \\
5.74 \\
-0.42 \\
-1.23 \\
5.03 \\
4.24 \\
-5.47 \\
1.03\end{array}$ & $\begin{array}{c}30.00 \\
17.60 \\
36.99 \\
19.00 \\
0.00 \\
2.23 \\
. \\
90.00 \\
43.70 \\
70.00 \\
68.00 \\
25.80 \\
39.60 \\
. \\
90.00\end{array}$ & $\begin{array}{c}35.00 \\
73.30 \\
6.67 \\
26.00 \\
85.00 \\
62.00 \\
. \\
0.01 \\
26.40 \\
8.00 \\
9.00 \\
56.70 \\
4.60 \\
. \\
0.01\end{array}$ & $\begin{array}{l}-1.11 \\
-0.15 \\
0.15 \\
0.54 \\
0.51 \\
0.71 \\
0.15 \\
0.18 \\
0.54 \\
-0.09 \\
-0.72 \\
0.13 \\
0.83 \\
-0.71 \\
-0.81\end{array}$ \\
\hline $\begin{array}{l}\text { Correlations: } \\
\text { w/SMEs as a } \\
\% \text { of Emp. }\end{array}$ & $0.145 * * *$ & $0.090 * * *$ & $0.06 * * *$ & $-0.548 * * *$ & $0.626 * * *$ & $0.258 * * *$ \\
\hline
\end{tabular}




\section{TABLE 7: Correlations Between Total Debt-to-Equity Ratios and Firm Characteristics}

Panel B reports correlation coefficients that are significant at the 5\% level; shaded patterns indicate that the sign agrees with the theoretical predictions in Panel A. FA/TA is the ratio of fixed to total assets. SALESUS is total sales in US\$. DEP/TA is the ratio of depreciation to total assets. Cash/TA is the ratio of cash to total assets. ROA is return on assets measured as the ratio of EBIT to total assets. AGE is the number of years since incorporation. AP/TL is the ratio of accounts payable to total liabilities. $* * *$, ** and $*$ indicate significance at the $1 \%, 5 \%$ and $10 \%$ level, respectively.

\begin{tabular}{|c|c|c|c|c|c|c|c|c|c|c|c|c|c|c|c|}
\hline $\begin{array}{l}\text { Correlation: } \\
\text { Total Debt/Equity }\end{array}$ & $\begin{array}{c}\text { Bosnia } \\
\text { Herzegovina }\end{array}$ & Bulgaria & Croatia & $\begin{array}{c}\text { Czech } \\
\text { Republic }\end{array}$ & Estonia & Hungary & Latvia & Lithuania & Poland & Romania & Russia & Slovakia & Slovenia & Ukraine & Yugoslavia \\
\hline FA/TA & $-0.568 * * *$ & $-0.183^{* * *}$ & $-0.316^{* * *}$ & -0.231 **** & $-0.13 * * *$ & $-0.291 * * *$ & $-0.225^{* * *}$ & $-0.243 * * *$ & $-0.27 * * *$ & $-0.133 * * *$ & $-0.465^{* * *}$ & $-0.271 * * *$ & $-0.437 * * *$ & $-0.291 * * *$ & $-0.504 * * *$ \\
\hline SALESUS & $0.136 * * *$ & 0.01 & -0.023 & $0.036^{*}$ & -0.002 & -0.004 & . & -0.051 & 0.00 & -0.008 & . & -0.025 & -1.00 & -0.002 & 0.035 \\
\hline DEP/TA & $-0.068^{* *}$ & $-0.126^{* * * *}$ & $-0.106^{* * *}$ & $-0.137 * * *$ & $-0.086^{* * * *}$ & $-0.172 * * *$ & . & . & $-0.241 * * *$ & $-0.09 * * *$ & . & $-0.113^{* * *}$ & $-0.294 * * *$ & $-0.063 * * *$ & $-0.242 * * *$ \\
\hline $\mathrm{CASH} / \mathrm{TA}$ & 0.094* & $-0.12 * * *$ & -0.009 & $-0.11 * * *$ & $-0.122 * * *$ & $-0.115^{* * *}$ & $-0.105^{* * *}$ & $-0.097^{*}$ & $-0.176^{* * *}$ & -0.011 & 0.012 & 0.008 & -0.024 & $-0.052 * * *$ & -0.016 \\
\hline AGE & $-0.125 * * *$ & $-0.163 * * *$ & $-0.253 * * *$ & $-0.031 *$ & $-0.096 * * *$ & $-0.034 * *$ & -0.029 & $-0.069 * *$ & $-0.058 * * *$ & $-0.014 *$ & $-0.055 * * *$ & $-0.144 * * *$ & -0.081 & $-0.071 * * *$ & -0.015 \\
\hline ROA & $0.185^{* * *}$ & $0.035 * * *$ & 0.028 & -0.001 & $-0.121 * * *$ & $-0.196 * * *$ & $-0.101 * * *$ & $-0.107 * * *$ & 0.007 & $0.077 * * *$ & $0.086^{* * *}$ & $0.18^{* * *}$ & $0.115^{* *}$ & $0.056^{* * *}$ & $0.069^{* * *}$ \\
\hline APTL & $-0.118 * * *$ & $0.102 * * *$ & & $-0.044 * *$ & $-0.198 * * *$ & $0.114 * * *$ & $-0.169 * * *$ & $-0.156^{* * *}$ & $-0.261 * * *$ & $-0.028 * * *$ & $-0.069 * * *$ & $-0.102 * * *$ & & $-0.026^{* * *}$ & $-0.128 * * *$ \\
\hline
\end{tabular}




\section{Table 8: Theories of Capital Structure: Relations with Debt}

This table shows the correlation coefficient sign predicted by various theories. SIZE is the natural log of total sales in US\$. AGE is the number of years since incorporation. PROFIT is measured by ROE, which is return on equity measured as the ratio of net income less stock dividends to common equity. GROWTH is the 1-year growth rate of sales. TANG is the ratio of fixed assets to total assets. NDTS are non-deb tax s

hields, measured as the ratio of depreciation to total assets.

\begin{tabular}{|l|c|c|c|c|c|c|}
\hline & SIZE & AGE & PROFIT & GROWTH & TANG & NDTS \\
\hline Static Trade Off & + & & & & + & - \\
\hline $\begin{array}{l}\text { Collateral value (Bankruptcy } \\
\text { costs) }\end{array}$ & + & & & & + & \\
\hline Agency problems & & + & & $+/-$ & - & \\
\hline Collateral value & & & & & - & \\
\hline Growing industries (+STD) & & & & $+/-$ & & \\
\hline Reputation & & + & & & & \\
\hline $\begin{array}{l}\text { Marginal tax rate \& Non- } \\
\text { debt tax shields }\end{array}$ & & & & & & \\
\hline Pecking Order (M\&M) & & & - & & + & \\
\hline Collateral value (\& Size) & & & & & + & \\
\hline Profitability & & & - & & & \\
\hline Risk shifting (J\&M) & & & & & + & \\
\hline Collateral value & & & & & + & \\
\hline Underinvestment (M) & & & & & + & \\
\hline Collateral value & & & & & + & + \\
\hline Free Cash Flow (J) & & & + & & + & + \\
\hline Collateral value & & & & & & + \\
\hline Profitability & & & + & & + & \\
\hline
\end{tabular}




\section{TABLE 9: OLS Regressions of the Determinants of Debt}

Panel B reports OLS regression results. Dependent variables are listed in the top row: LIAB/EQ is the ratio of total liabilities to the book value of equity; $D E B T / E Q$ is the ratio of total debt to equity; $S T D / E Q$ is the ratio of short-term debt to equity; $L T D / E Q$ is the ratio of long-term debt to equity. SIZE is the natural $\log$ of total sales in US\$. $A G E$ is the number of years since incorporation. GROWTH is the 1-year growth rate of sales. PROFIT is measured by ROE, which is return on equity measured as the ratio of net income less stock dividends to common equity. TANGIBILITY is the ratio of fixed assets to total assets. NDTS are non-deb tax shields, measured as the ratio of depreciation to total assets. All regressions include industry (SIC) and country dummies. T-statistics are shown in parentheses. $* * *, * *$ and $*$ indicate significance at the $1 \%, 5 \%$ and $10 \%$ level, respectively.

\begin{tabular}{|c|c|c|c|c|}
\hline & LIAB/EQ & DEBT/EQ & STD/EQ & LTD/EQ \\
\hline Constant & $\begin{array}{c}1.215^{* *} \\
(2.38)\end{array}$ & $\begin{array}{c}1.241 * * * \\
(2.55)\end{array}$ & $\begin{array}{c}1.510 * * * \\
(3.23)\end{array}$ & $\begin{array}{c}-0.269 * * * \\
(-2.76)\end{array}$ \\
\hline SIZE & $\begin{array}{c}0.084 * * * \\
(3.52)\end{array}$ & $\begin{array}{c}0.080 * * * \\
(3.51) \\
\end{array}$ & $\begin{array}{c}0.059 * * * \\
(2.70) \\
\end{array}$ & $\begin{array}{c}0.021 * * * \\
(4.63)\end{array}$ \\
\hline AGE & $\begin{array}{c}-0.002^{* *} * \\
(-1.95)\end{array}$ & $\begin{array}{c}-0.017 * * \\
(-1.99)\end{array}$ & $\begin{array}{l}-0.001 \\
(-1.57)\end{array}$ & $\begin{array}{c}-0.001 * * \\
(-2.43)\end{array}$ \\
\hline GROWTH & $\begin{array}{c}0.014 * * * \\
(16.12)\end{array}$ & $\begin{array}{c}0.013 * * * \\
(15.83)\end{array}$ & $\begin{array}{c}0.012 * * * \\
(15.46)\end{array}$ & $\begin{array}{c}0.001 * * * \\
(5.01)\end{array}$ \\
\hline PROFIT & $\begin{array}{c}0.636^{* * * *} \\
(11.26)\end{array}$ & $\begin{array}{c}0.678 * * * \\
(12.60)\end{array}$ & $\begin{array}{c}0.696^{* * *} \\
(13.49)\end{array}$ & $\begin{array}{c}-0.018^{*} \\
(-1.68)\end{array}$ \\
\hline TANGIBILITY & $\begin{array}{c}-2.420 * * * \\
(-22.71)\end{array}$ & $\begin{array}{c}-2.391 * * * \\
(-23.57)\end{array}$ & $\begin{array}{c}-2.555 * * * \\
(-26.25)\end{array}$ & $\begin{array}{c}0.164 * * * \\
(8.06)\end{array}$ \\
\hline NDTS & $\begin{array}{c}-8.973 * * * \\
(-9.05) \\
\end{array}$ & $\begin{array}{c}-8.694 * * * \\
(-9.21) \\
\end{array}$ & $\begin{array}{c}-8.091 * * * \\
(-8.94) \\
\end{array}$ & $\begin{array}{c}-0.603 * * * \\
(-3.19) \\
\end{array}$ \\
\hline $\begin{array}{l}\text { Industry } \\
\text { Dummies }\end{array}$ & Yes & Yes & Yes & Yes \\
\hline $\begin{array}{l}\text { Country } \\
\text { Dummies }\end{array}$ & Yes & Yes & Yes & Yes \\
\hline Observations & 28,673 & 28,673 & 28,673 & 28,673 \\
\hline Adj. R-sq & 0.06 & 0.07 & 0.08 & 0.03 \\
\hline
\end{tabular}




\section{Figure 1: A Comparison of Leverage of SMEs versus Large Firms}

This figure shows a scatterplot of the leverage of SMEs and large firms against a slope line equal to one.

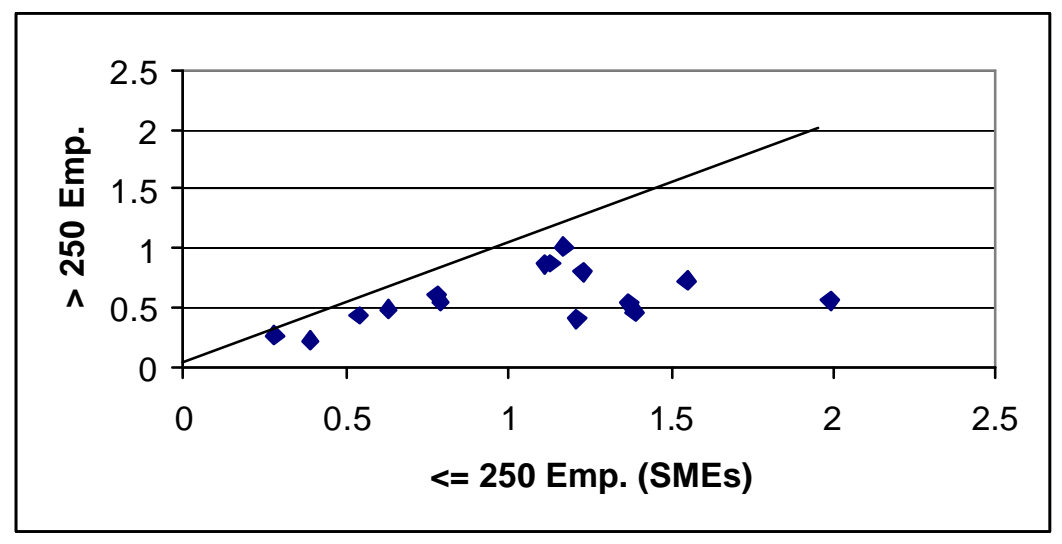




\section{Appendix 1: Median Summary Statistics, Employment $<10,1999$}

Sample includes all nonfinancial, private, and publicly traded firms with less than 10 employees. Current Ratio equals the ratio of current assets to current liabilities. Cash Ratio equals the ratio of cash to current liabilities. ROE equals the ratio of net income to equity. ROA equals the ratio of EBIT to total assets.

\begin{tabular}{|c|c|c|c|c|c|c|c|c|c|c|c|c|c|c|c|}
\hline $\begin{array}{l}\text { \# Employees } \\
<10\end{array}$ & $\begin{array}{c}\text { Bosnia- } \\
\text { Herzegovina }\end{array}$ & Bulgaria & Croatia & $\begin{array}{c}\text { Czech } \\
\text { Republic }\end{array}$ & Estonia & Hungary & Latvia & Lithuania & Poland & Romania & Russia & Slovakia & Slovenia & Ukraine & Yugoslavia \\
\hline $\begin{array}{l}\text { No. } \\
\text { Observations }\end{array}$ & 86 & 21,539 & 13,769 & 698 & 16,157 & 1,292 & 562 & 182 & 525 & 173,787 & 6 & 204 & 6 & 3 & 392 \\
\hline $\begin{array}{l}\text { Total No. } \\
\text { Employees }\end{array}$ & 558 & 108,106 & 48,253 & 3,490 & 57,644 & 6,815 & 3,119 & 1,075 & 2,529 & 475,085 & 20 & 605 & 26 & 13 & 1,970 \\
\hline $\begin{array}{l}\text { Employees } \\
\text { (median) }\end{array}$ & 8 & 5 & 3 & 5 & 3 & 5 & 6 & 6 & 5 & 2 & 3 & 2 & 5 & 5 & 5 \\
\hline Sales (U\$S) & 163,652 & 56,633 & 180,529 & 410,235 & 35,313 & 692,045 & . & 562,675 & $1,101,558$ & 10,023 & . & 120,446 & . & $2,219,266$ & 185,238 \\
\hline Assets (U\$S) & 102,406 & 27,772 & 95,466 & 780,144 & 15,291 & 286,933 & 135,416 & 303,323 & $8,199,802$ & 2,590 & $5,712,463$ & 938,040 & 64,367 & $5,106,366$ & 158,346 \\
\hline Age & 6 & 4 & 6 & 4 & 3 & 6 & 4 & 4 & 4 & 5 & 2 & 3 & 7 & 5 & 7 \\
\hline $\begin{array}{l}\text { Liabilities / } \\
\text { Equity }\end{array}$ & 1.9 & 0.45 & 3.78 & 0.32 & 0.73 & 1.53 & 1.87 & 1.26 & 0.65 & 0.67 & 3.75 & 0.49 & 0.86 & 1.69 & 3.02 \\
\hline Debt / Equity & 1.77 & 0.37 & 3.4 & 0.3 & 0.7 & 1.27 & 1.75 & 1.24 & 0.64 & 0.47 & 3.75 & 0.47 & 0.69 & 1.69 & 2.97 \\
\hline $\begin{array}{l}\text { Acct Pay / } \\
\text { Equity }\end{array}$ & 0.1 & 0.00 & . & 0.00 & 0.09 & 1.2 & 0.15 & 0.15 & 0.16 & 0.23 & 0.00 & 0.00 & . & 1.63 & 0.13 \\
\hline Current Ratio & 1.12 & 1.33 & 1.09 & 1.26 & 1.17 & 1.19 & 1.19 & 1.27 & 1.03 & 0.97 & 1.08 & 1.02 & 1.17 & 0.86 & 1.13 \\
\hline Cash Ratio & 0.05 & 0.33 & 0.08 & 0.2 & 0.23 & 0.19 & 0.12 & 0.08 & 0.27 & 0.1 & 0.02 & 0.12 & 0.09 & 0.00 & 0.05 \\
\hline $\begin{array}{l}\text { Fixed Assets / } \\
\text { Total Assets }\end{array}$ & 0.22 & 0.22 & 0.14 & 0.32 & 0.24 & 0.24 & 0.18 & 0.25 & 0.48 & 0.16 & 0.06 & 0.51 & 0.31 & 0.44 & 0.13 \\
\hline ROE & 0.05 & 0.13 & 0.26 & 0.01 & 0.04 & 0.26 & 0.3 & 0.16 & 0.09 & 0.17 & 0.06 & 0.00 & 0.04 & 0.00 & 0.1 \\
\hline ROA & 0.04 & 0.06 & 0.08 & 0.03 & 0.00 & 0.09 & 0.1 & 0.08 & 0.05 & 0.00 & 0.08 & 0.02 & 0.00 & 0.03 & 0.03 \\
\hline $\begin{array}{l}\text { 1-Yr Sales } \\
\text { Growth }\end{array}$ & . & 1.23 & -4.96 & -7.34 & -11.41 & 7.08 & . & -4.24 & 1.33 & -24.33 & . & -16.99 & . & . & 25.46 \\
\hline Agriculture $\%$ & 0.09 & 0.06 & 0.02 & 0.02 & 0.14 & 0.04 & 0.02 & 0.02 & 0.01 & 0.1 & 0.01 & 0.02 & 0.01 & 0.17 & 0.02 \\
\hline Industry $\%$ & 0.17 & 0.25 & 0.19 & 0.1 & 0.19 & 0.41 & 0.16 & 0.26 & 0.22 & 0.4 & 0.33 & 0.1 & 0.23 & 0.17 & 0.21 \\
\hline Service $\%$ & 0.67 & 0.64 & 0.7 & 0.83 & 0.54 & 0.52 & 0.81 & 0.69 & 0.57 & 0.49 & 0.57 & 0.81 & 0.57 & 0.5 & 0.74 \\
\hline
\end{tabular}


Appendix 2: Firm-Level Variables Available in Amadeus

\begin{tabular}{|l|l|}
\hline 1 & Added Value \\
\hline 2 & Capital \\
\hline 3 & Cash Flow \\
\hline 4 & Cash and Cash Equivalents \\
\hline 5 & Costs of Employees \\
\hline 6 & Cost of Good Sold \\
\hline 7 & Current Assets \\
\hline 8 & Current Liabilities \\
\hline 9 & Depreciation \\
\hline 10 & Extraordinary Expenses \\
\hline 11 & Extraordinary Revenue \\
\hline 12 & Extraordinary P/L \\
\hline 13 & Fixed Assets \\
\hline 14 & Financial Expenses \\
\hline 15 & Financial P/L \\
\hline 16 & Financial Revenue \\
\hline 17 & Gross Profit \\
\hline 18 & Intangible Fixed Assets \\
\hline 19 & Interest Paid \\
\hline 20 & Loans \\
\hline 21 & Long Term Debt \\
\hline 22 & Material Costs \\
\hline 23 & Non Current Liabilities \\
\hline 24 & Number of Employees \\
\hline 25 & Other Current Assets \\
\hline 26 & Other Fixed Assets \\
\hline 27 & Other Non-Current Liabilities \\
\hline 28 & Other Operating Expenses \\
\hline 29 & Operating P/L \\
\hline 30 & Operating Revenue/Turnover \\
\hline 31 & Other Shareholders Funds \\
\hline 32 & P/L for Period \\
\hline 33 & P/L After Tax \\
\hline 34 & P/L Before Tax \\
\hline 35 & Sales \\
\hline 36 & Stocks \\
\hline 37 & Taxation \\
\hline 38 & Tangible Fixed Assets \\
\hline 39 & Total Assets \\
\hline 40 & Total Shareholder Funds and Liabilities \\
\hline 41 & Working Capital \\
\hline & \\
\hline
\end{tabular}


Annex: Table 2: Mean Summary Statistics, All Countries 1999

\begin{tabular}{|c|c|c|c|c|c|c|}
\hline & All firms & Employees <= 250 & Employees $>250$ & Firm Age 1-3 & Firm Age 3-10 & Firm Age 10+ \\
\hline \# Observations & 97,107 & 79,723 & 16,917 & 13,206 & 47,863 & 9,367 \\
\hline Total \# Employees & $22,005,131$ & $5,277,815$ & $16,610,566$ & $2,869,021$ & $8,850,285$ & $6,028,548$ \\
\hline Change in Employment & $-1,026,083$ & $-266,977$ & $-759,643$ & $-17,855$ & $-399,427$ & $-514,452$ \\
\hline Employees (Average) & 227 & 66 & 982 & 217 & 184.91 & 644 \\
\hline Sales (U\$S) & $688,536,923$ & $169,374,972$ & $3,397,952,178$ & $4,179,660$ & 15543485 & $13,524,111$ \\
\hline Assets (U\$S) & $599,680,792$ & $83,985,525$ & 2,994,675,796 & $6,515,640$ & 27570693 & $22,841,165$ \\
\hline Age & 11.38 & 8.27 & 24.46 & 1.77 & 6.59 & 49.40 \\
\hline Liabilities / Equity & 2.53 & 2.84 & 1.15 & 3.35 & 3.06 & 1.09 \\
\hline Debt / Equity & 2.35 & 2.63 & 1.07 & 3.11 & 2.88 & 0.99 \\
\hline Acct Pay / Equity & 0.72 & 0.81 & 0.30 & 0.95 & 0.96 & 0.23 \\
\hline Current Ratio & 1.40 & 1.37 & 1.53 & 1.21 & 1.28 & 1.59 \\
\hline Cash Ratio & 0.18 & 0.19 & 0.12 & 0.15 & 0.17 & 0.14 \\
\hline Fixed Assets / Total Assets & 0.50 & 0.45 & 0.70 & 0.45 & 0.47 & 0.63 \\
\hline ROE & 0.19 & 0.23 & -0.01 & 0.29 & 0.25 & -0.03 \\
\hline ROA & 0.07 & 0.08 & 0.05 & 0.07 & 0.1 & 0.03 \\
\hline 1-Yr Sales Growth & -1.18 & -0.54 & -6.21 & 12.27 & -5.28 & -6.99 \\
\hline Agriculture $\%$ & 0.11 & 0.11 & 0.14 & 0.11 & 0.09 & 0.09 \\
\hline Industry $\%$ & 0.47 & 0.45 & 0.57 & 0.45 & 0.5 & 0.59 \\
\hline Service $\%$ & 0.38 & 0.41 & 0.24 & 0.40 & 0.38 & 0.26 \\
\hline
\end{tabular}


Annex: Table 3: Mean Summary Statistics, 1999

\begin{tabular}{|c|c|c|c|c|c|c|c|c|c|c|c|c|c|c|c|}
\hline ll Firms & $\begin{array}{c}\text { Bosnia } \\
\text { Herzegovina }\end{array}$ & Bulgaria & Croatia & $\begin{array}{c}\text { Czech } \\
\text { Republic }\end{array}$ & Estonia & Hungary & Latvia & Lithuania & Poland & Romania & $\begin{array}{c}\text { Russian } \\
\text { Federation }\end{array}$ & Slovakia & Slovenia & Ukraine & Yugoslavia \\
\hline Observations & 935 & 15941 & 4271 & 5500 & 5783 & 4260 & 1864 & 774 & 9484 & 27335 & 2889 & 1221 & 297 & 14326 & 2227 \\
\hline $\begin{array}{l}\text { 'otal \# } \\
\text { imployees }\end{array}$ & 148116 & 1341327 & 587482 & 1472955 & 266252 & 831761 & 275167 & 150566 & 3220987 & 3020744 & 2649311 & 648695 & 80267 & 6509729 & 801772 \\
\hline $\begin{array}{l}\text { 'hange in } \\
\text { imployment } \\
\text { imployees }\end{array}$ & 158 & -65607 & -12958 & 0.00 & -3262 & 3163 & -35 & -18517 & -213784 & -98732 & -54195 & 0.00 & 0.00 & -564158 & 2002 \\
\hline ales (U\$S) & 1271720 & 991788 & 5268729 & 12309426 & 1011904 & 9620355 & . & 4461688 & 19832401 & 1096082 & . & 11789240 & 37506108 & 6030246577 & 8307842 \\
\hline issets (U\$S) & 3502710 & 965097 & 12113719 & 13028027 & 942547 & 6756339 & 3323274 & 4431541 & 20842058 & 1196670 & 47463272 & 18540688 & 24135819 & 3926479101 & 27780825 \\
\hline Ige & 20.74 & 20.64 & 25.38 & 9.23 & 7.16 & 6.17 & 5.65 & 4.91 & 20.98 & 5.69 & 12.66 & 6.43 & 12.31 & 21.38 & 26.2 \\
\hline & 9.36 & 2.06 & -1251.57 & 4.13 & 41.2 & 4.93 & 3.67 & 14.43 & 6.31 & 22.89 & 24.17 & 10.29 & 1.68 & 5.37 & 11.35 \\
\hline lebt / Equity & 1.04 & 1.5 & 4.57 & 2.54 & 2.55 & 1.84 & 2.18 & 1.63 & 2.02 & 3.73 & 1.82 & 2.69 & 1.25 & 0.52 & 1.29 \\
\hline Icct Pay / Equity & 2.55 & 0.74 & . & -0.05 & 2.24 & 2.93 & 0.73 & 6.22 & 0.68 & 12.27 & 0.43 & 0.35 & . & 1.00 & 1.08 \\
\hline 'urrent Ratio & 1.61 & 3.48 & 1.68 & 3.89 & 3.95 & 1.99 & 3.31 & 2.09 & 1.51 & 7.01 & 2.03 & 1.93 & 1.76 & 2.42 & 2.37 \\
\hline 'ash Ratio & 0.13 & 0.8 & 0.18 & 0.96 & 1.92 & 0.64 & 0.43 & 0.41 & 0.29 & 0.46 & 0.21 & 0.46 & 0.09 & 0.18 & 0.12 \\
\hline $\begin{array}{l}\text { "ixed Assets / } \\
\text { 'otal Assets }\end{array}$ & 0.65 & 0.46 & 0.41 & 0.43 & 0.47 & 0.39 & 0.42 & 0.51 & 0.5 & 0.45 & 0.45 & 0.49 & 0.5 & 0.72 & 0.51 \\
\hline & 0.05 & 0.09 & 0.17 & 0.11 & 0.08 & 0.21 & 0.19 & 0.16 & 0.12 & 0.45 & -0.28 & 0.03 & 0.05 & -0.02 & 0.00 \\
\hline :OA & 0.04 & 0.03 & 0.06 & 0.08 & 0.04 & 0.1 & 0.12 & 0.1 & 0.09 & 0.12 & 0.00 & 0.05 & 0.01 & 0.04 & 0.03 \\
\hline $\begin{array}{l}\text {-Yr Sales } \\
\text { Jrowth }\end{array}$ & . & 7.67 & -3.36 & -2.72 & -2.91 & 9.02 & - & 11.38 & -3.08 & -5.26 & . & -7.71 & . & -99.15 & 2.67 \\
\hline igricuiture \% & 0.1 & 0.14 & 0.04 & 0.06 & 0.11 & 0.06 & 0.02 & 0.02 & 0.01 & 0.12 & 0.03 & 0.07 & 0.02 & 0.3 & 0.07 \\
\hline ndu & 0.48 & 0.42 & 0.41 & 0.39 & 0.36 & 0.63 & 0.35 & 0.41 & 0.52 & 0.56 & 0.51 & 0.4 & 0.56 & 0.38 & 0.51 \\
\hline ierv & 0.38 & 0.42 & 0.5 & 0.5 & 0.46 & 0.3 & 0.58 & 0.55 & 0.4 & 0.32 & 0.36 & 0.45 & 0.38 & 0.26 & 0.38 \\
\hline
\end{tabular}


Annex: Table 4a: Mean Summary Statistics, by number employment, 1999

\begin{tabular}{|c|c|c|c|c|c|c|c|c|c|c|c|c|c|c|c|}
\hline $\begin{array}{l}\text { Panel A: } \\
\text { Employees }<250\end{array}$ & $\begin{array}{c}\text { Bosnia } \\
\text { Herzegovina }\end{array}$ & Bulgaria & Croatia & $\begin{array}{c}\text { Czech } \\
\text { Republic }\end{array}$ & Estonia & Hungary & Latvia & Lithuania & Poland & Romania & $\begin{array}{l}\text { Russian } \\
\text { Federation }\end{array}$ & Slovakia & Slovenia & Ukraine & Yugoslavia \\
\hline \# Observations & 812 & 15123 & 3838 & 4301 & 5656 & 3614 & 1634 & 638 & 6746 & 25535 & 1415 & 831 & 202 & 7783 & 1595 \\
\hline Firms $\%$ & 87 & 95 & 90 & 78 & 98 & 85 & 88 & 82 & 71 & 93 & 49 & 68 & 68 & 54 & 72 \\
\hline $\begin{array}{l}\text { Total \# } \\
\text { Employees }\end{array}$ & 69055 & 672585 & 200833 & 390455 & 189921 & 228882 & 111447 & 39062 & 685245 & 1025099 & 209703 & 73945 & 24757 & 1193852 & 162974 \\
\hline Employees \% & 47 & 50 & 34 & 27 & 71 & 28 & 41 & 26 & 21 & 34 & 8 & 11 & 31 & 18 & 20 \\
\hline $\begin{array}{l}\text { Change in Total } \\
\text { Employment }\end{array}$ & . & -40114 & -3478 & . & -5138 & 3474 & 2194 & -12429 & -38491 & -51977 & -19400 & . & . & -102255 & 637 \\
\hline $\begin{array}{l}\text { Employees } \\
\text { (Average) }\end{array}$ & 85 & 44 & 52 & 91 & 34 & 63 & 68 & 61 & 102 & 40 & 148 & 89 & 123 & 153 & 102 \\
\hline Sales (U\$S) & 810958 & 560738 & 3068600 & 5819178 & 879615 & 4682422 & . & 3445600 & 9266058 & 599386 & . & 2530583 & 33301528 & 2884418841 & 3431848 \\
\hline Assets (U\$S) & 2200415 & 453463 & 3973781 & 5482818 & 751284 & 2883350 & 1826334 & 3609046 & 9123688 & 425333 & 13046905 & 4875179 & 11718026 & 821773435 & 6718309 \\
\hline$\%$ Age $0-3$ & 11 & 7 & 12 & 19 & 23 & 20 & 20 & 29 & 16 & 18 & 27 & 24 & 10 & 56 & 9 \\
\hline Age & 19.15 & 16.84 & 19.6 & 6.79 & 6.95 & 6.07 & 5.61 & 4.81 & 15.15 & 5.55 & 6.65 & 6.2 & 11.21 & 6.73 & 19.88 \\
\hline $\begin{array}{l}\text { Liabilities / } \\
\text { Equity }\end{array}$ & 1.13 & 1.68 & 5.91 & 2.83 & 2.68 & 2.23 & 2.66 & 1.82 & 2.4 & 4.13 & 2.43 & 3.09 & 1.75 & 0.58 & 1.52 \\
\hline Debt / Equity & 1.09 & 1.52 & 4.9 & 2.69 & 2.58 & 1.91 & 2.34 & 1.77 & 2.28 & 3.9 & 2.41 & 2.94 & 1.42 & 0.55 & 1.47 \\
\hline Acct Pay / Equity & 0.14 & 0.3 & . & 0.07 & 0.43 & 1.79 & 0.37 & 0.21 & 0.4 & 1.62 & 0.03 & 0.11 & . & 0.22 & 0.13 \\
\hline Current Ratio & 1.26 & 1.71 & 1.25 & 1.74 & 1.26 & 1.42 & 1.58 & 1.45 & 1.31 & 1.03 & 1.57 & 1.42 & 1.41 & 1.64 & 1.8 \\
\hline Cash Ratio & 0.06 & 0.33 & 0.09 & 0.33 & 0.24 & 0.21 & 0.18 & 0.13 & 0.17 & 0.14 & 0.15 & 0.2 & 0.06 & 0.06 & 0.06 \\
\hline $\begin{array}{l}\text { Fixed Assets / } \\
\text { Total Assets }\end{array}$ & 0.64 & 0.46 & 0.4 & 0.41 & 0.46 & 0.37 & 0.4 & 0.38 & 0.5 & 0.41 & 0.41 & 0.46 & 0.48 & 0.65 & 0.49 \\
\hline ROE & 0.05 & 0.09 & 0.19 & 0.12 & 0.09 & 0.22 & 0.2 & 0.18 & 0.15 & 0.47 & -0.11 & 0.06 & 0.06 & 0.01 & 0.01 \\
\hline ROA & 0.04 & 0.03 & 0.06 & 0.08 & 0.04 & 0.1 & 0.12 & 0.1 & 0.1 & 0.12 & 0.06 & 0.05 & 0.01 & 0.04 & 0.03 \\
\hline $\begin{array}{l}\text { 1-Yr Sales } \\
\text { Growth }\end{array}$ & $\cdot$ & 8.19 & -3.00 & -2.76 & -3.02 & 9.83 & . & 12.65 & -2.65 & -4.97 & $\cdot$ & -7.99 & . & . & 4.77 \\
\hline Agriculture \% & 0.11 & 0.15 & 0.04 & 0.06 & 0.12 & 0.05 & 0.02 & 0.02 & 0.02 & 0.12 & 0.01 & 0.08 & 0.02 & 0.27 & 0.07 \\
\hline Industry $\%$ & 0.45 & 0.4 & 0.39 & 0.33 & 0.36 & 0.6 & 0.33 & 0.33 & 0.48 & 0.55 & 0.4 & 0.29 & 0.46 & 0.35 & 0.45 \\
\hline Service $\%$ & 0.4 & 0.42 & 0.52 & 0.55 & 0.46 & 0.32 & 0.61 & 0.64 & 0.46 & 0.33 & 0.46 & 0.54 & 0.46 & 0.31 & 0.43 \\
\hline
\end{tabular}


Annex: Table 4b: Mean Summary Statistics, by number employment, 1999

\begin{tabular}{|c|c|c|c|c|c|c|c|c|c|c|c|c|c|c|c|}
\hline $\begin{array}{l}\text { inel B: } \\
\text { nployees > } 250\end{array}$ & $\begin{array}{c}\text { Bosnia } \\
\text { Herzegovina }\end{array}$ & Bulgaria & Croatia & $\begin{array}{c}\text { Czech } \\
\text { Republic }\end{array}$ & Estonia & Hungary & Latvia & Lithuania & Poland & Romania & $\begin{array}{c}\text { Russian } \\
\text { Federation }\end{array}$ & Slovakia & Slovenia & Ukraine & Yugoslavi \\
\hline Jbservations & 123 & 816 & 431 & 945 & 125 & 623 & 230 & 135 & 2710 & 1782 & 1468 & 333 & 94 & 6477 & 625 \\
\hline $\mathrm{ms} \%$ & 13 & 5 & 10 & 17 & 2 & 15 & 12 & 17 & 29 & 7 & 51 & 27 & 32 & 45 & 28 \\
\hline $\begin{array}{l}\text { ital \# } \\
\text { nployees }\end{array}$ & 79061 & 668242 & 386149 & 1019000 & 75831 & 597129 & 163720 & 111254 & 2528742 & 1991145 & 2438108 & 560500 & 55260 & 5299377 & 637048 \\
\hline nployees \% & 53 & 50 & 66 & 69 & 28 & 72 & 59 & 74 & 79 & 66 & 92 & 86 & 69 & 81 & 79 \\
\hline $\begin{array}{l}\text { lange in Total } \\
\text { nployment }\end{array}$ & & -25508 & -9492 & . & 1851 & -549 & -2229 & -6037 & -175485 & -47821 & -35064 & . & . & -460674 & 1365 \\
\hline $\begin{array}{l}\text { nployees } \\
\text { verage) }\end{array}$ & 642.77 & 818.92 & 895.94 & 1078.31 & 606.65 & 958.47 & 711.83 & 824.10 & 933.12 & 1117.37 & 1660.84 & 1683.18 & 587.87 & 818.18 & 1019.28 \\
\hline les (U\$S) & 4323328 & 8727831 & 30114560 & 41216403 & 6920816 & 40956545 & . & 9592277.69 & 45660032 & 8148126 & . & 32505364 & 41710686 & 8453088590 & 2071864 \\
\hline isets (U\$S) & 12099972 & 10198138 & 84630621 & 46916688 & 9589680 & 31967863 & 13958058 & 8328681.46 & 41193743 & 12246768 & 80825473 & 53969141 & 50708157 & 7646922441 & 8164411 \\
\hline ge $0-3$ & 0 & 3 & 7 & 12 & 16 & 9 & 13 & 9 & 9 & 15 & 16 & 21 & 2 & 33 & 2 \\
\hline se & 31.26 & 35.03 & 46.69 & 21.02 & 16.88 & 6.72 & 5.9 & 5.41 & 35.57 & 7.7 & 18.52 & 6.95 & 14.55 & 27.39 & 42.39 \\
\hline $\begin{array}{l}\text { abilities / } \\
\text { |uity }\end{array}$ & 0.67 & 1.25 & 2.07 & 2.1 & 1.31 & 1.73 & 1.27 & 0.86 & 1.67 & 1.46 & 1.32 & 2.24 & 1.14 & 0.51 & 0.88 \\
\hline :bt / Equity & 0.67 & 1.07 & 1.63 & 2.03 & 1.04 & 1.44 & 1.05 & 0.86 & 1.59 & 1.37 & 1.31 & 2.22 & 0.94 & 0.48 & 0.85 \\
\hline ct Pay / Equity & 0.11 & 0.22 & . & 0.07 & 0.3 & 1.24 & 0.27 & 0.17 & 0.39 & 0.72 & 0.03 & 0.11 & . & 0.22 & 0.12 \\
\hline Irrent Ratio & 1.45 & 1.67 & 1.39 & 1.6 & 1.33 & 1.34 & 1.91 & 1.71 & 1.26 & 1.25 & 1.56 & 1.33 & 1.54 & 1.65 & 2.05 \\
\hline sh Ratio & 0.04 & 0.25 & 0.08 & 0.26 & 0.23 & 0.17 & 0.27 & 0.12 & 0.18 & 0.14 & 0.1 & 0.13 & 0.05 & 0.04 & 0.07 \\
\hline $\begin{array}{l}\text { xed Assets / } \\
\text { ital Assets }\end{array}$ & 0.78 & 0.62 & 0.58 & 0.53 & 1.1 & 0.52 & 0.58 & 1.09 & 0.51 & 0.99 & 0.48 & 0.56 & 0.56 & 0.81 & 0.57 \\
\hline JE & 0.02 & 0.05 & 0.00 & 0.06 & 0.03 & 0.11 & 0.1 & 0.05 & 0.06 & 0.17 & -0.44 & -0.01 & 0.04 & -0.03 & -0.01 \\
\hline )A & 0.03 & 0.03 & 0.02 & 0.08 & 0.07 & 0.07 & 0.1 & 0.09 & 0.07 & 0.14 & -0.06 & 0.06 & 0.01 & 0.03 & 0.03 \\
\hline $\begin{array}{l}\text { Yr Sales } \\
\text { owth }\end{array}$ & . & -1.88 & -8.28 & -4.12 & 0.68 & 3.86 & . & 5.68 & -4.03 & -15.02 & . & -13.78 & . & -99.15 & -2.86 \\
\hline sriculture \% & 0.08 & 0.04 & 0.05 & 0.03 & 0.06 & 0.06 & 0.03 & 0.05 & 0.01 & 0.07 & 0.04 & 0.03 & 0.00 & 0.32 & 0.08 \\
\hline Justry \% & 0.68 & 0.69 & 0.6 & 0.62 & 0.54 & 0.72 & 0.51 & 0.78 & 0.64 & 0.69 & 0.62 & 0.68 & 0.77 & 0.41 & 0.67 \\
\hline rvice $\%$ & 0.22 & 0.25 & 0.32 & 0.3 & 0.36 & 0.2 & 0.39 & 0.16 & 0.26 & 0.22 & 0.27 & 0.25 & 0.21 & 0.22 & 0.24 \\
\hline
\end{tabular}


Annex: Table 5a: Mean Summary Statistics, by number age, 1999

\begin{tabular}{|c|c|c|c|c|c|c|c|c|c|c|c|c|c|c|c|}
\hline $\begin{array}{l}\text { Panel C: } \\
\text { Firm Age 0-3 }\end{array}$ & $\begin{array}{c}\text { Bosnia } \\
\text { Herzegovina }\end{array}$ & Bulgaria & Croatia & $\begin{array}{c}\text { Czech } \\
\text { Republic }\end{array}$ & Estonia & Hungary & Latvia & Lithuania & Poland & Romania & $\begin{array}{l}\text { Russian } \\
\text { Federation }\end{array}$ & Slovakia & Slovenia & Ukraine & Yugoslavia \\
\hline \# Observations & 89 & 118 & 216 & 903 & 1306 & 706 & 349 & 194 & 1254 & 4868 & 598 & 284 & 22 & 2146 & 153 \\
\hline Firms $\%$ & 10 & 1 & 5 & 16 & 23 & 17 & 19 & 25 & 13 & 18 & 21 & 23 & 7 & 15 & 7 \\
\hline $\begin{array}{l}\text { Total \# } \\
\text { Employees }\end{array}$ & 3044 & 13266 & 51625 & 151270 & 47362 & 61552 & 32205 & 17538 & 244774 & 571564 & 272045 & 106175 & 3488 & 1239160 & 53953 \\
\hline Employees \% & 2 & 1 & 9 & 10 & 18 & 7 & 12 & 12 & 8 & 19 & 10 & 16 & 4 & 19 & 7 \\
\hline $\begin{array}{l}\text { Change in Total } \\
\text { Employment }\end{array}$ & . & 3171 & 1460 & . & 583 & 2483 & 1269 & 676 & 11976 & 47246 & 8111 & . & . & -94783 & -47 \\
\hline $\begin{array}{l}\text { Employees } \\
\text { (Average) }\end{array}$ & 34 & 112 & 239 & 168 & 36 & 87 & 92 & 90 & 195 & 117 & 455 & 374 & 159 & 577 & 353 \\
\hline Sales (U\$S) & 884071 & 2297780 & 7777367 & 8499026 & 763882 & 4905152 & . & 1869925 & 12266975 & 1124870 & . & 5465811 & . & 6407192 & 9375622 \\
\hline Assets (U\$S) & 895527 & 1987798 & 17022904 & 7543118 & 703578 & 3202051 & 2498549 & 1649281 & 14655804 & 1378096 & 26441823 & 13102159 & 10685623 & 11108367 & 37607856 \\
\hline Age & 2.39 & 1.88 & 1.99 & 1.91 & 1.73 & 2.22 & 2.08 & 1.88 & 1.88 & 1.57 & 1.93 & 1.99 & 2.05 & 1.78 & 2.08 \\
\hline $\begin{array}{l}\text { Liabilities / } \\
\text { Equity }\end{array}$ & 2.31 & 2.51 & 7.78 & 3.95 & 3.69 & 2.76 & 3.83 & 1.93 & 2.59 & 4.57 & 2.67 & 3.43 & 2.34 & 0.66 & 2.38 \\
\hline Debt / Equity & 2.14 & 2.11 & 6.03 & 3.8 & 3.49 & 2.34 & 3.26 & 1.87 & 2.47 & 4.26 & 2.66 & 3.43 & 1.84 & 0.61 & 2.31 \\
\hline Acct Pay / Equity & 0.19 & 0.5 & . & 0.08 & 0.55 & 2.17 & 0.43 & 0.24 & 0.44 & 1.76 & 0.03 & 0.12 & . & 0.25 & 0.19 \\
\hline Current Ratio & 1.25 & 1.37 & 1.21 & 1.5 & 1.11 & 1.32 & 1.33 & 1.43 & 1.19 & 0.97 & 1.56 & 1.27 & 1.24 & 1.51 & 1.55 \\
\hline Cash Ratio & 0.07 & 0.28 & 0.07 & 0.28 & 0.23 & 0.2 & 0.15 & 0.14 & 0.18 & 0.14 & 0.14 & 0.14 & 0.07 & 0.06 & 0.06 \\
\hline $\begin{array}{l}\text { Fixed Assets / } \\
\text { Total Assets }\end{array}$ & 0.41 & 0.43 & 0.35 & 0.37 & 0.41 & 0.37 & 0.42 & 0.39 & 0.42 & 0.39 & 0.35 & 0.49 & 0.39 & 0.7 & 0.34 \\
\hline ROE & 0.15 & 0.23 & 0.18 & 0.14 & 0.2 & 0.25 & 0.24 & 0.2 & 0.15 & 0.57 & -0.22 & 0.03 & 0.02 & -0.02 & 0.01 \\
\hline ROA & 0.06 & 0.07 & 0.04 & 0.07 & 0.04 & 0.09 & 0.1 & 0.1 & 0.08 & 0.09 & 0.03 & 0.04 & 0.01 & 0.04 & 0.04 \\
\hline $\begin{array}{l}\text { 1-Yr Sales } \\
\text { Growth }\end{array}$ & . & 39.05 & 3.76 & 2.17 & 5.99 & 17.79 & . & 24.13 & 6.25 & 15.63 & . & -4.16 & . & . & 14.99 \\
\hline Agriculture \% & 0.04 & 0.00 & 0.08 & 0.05 & 0.14 & 0.03 & 0.01 & 0.01 & 0.01 & 0.14 & 0.04 & 0.02 & 0.00 & 0.19 & 0.03 \\
\hline Industry $\%$ & 0.39 & 0.46 & 0.44 & 0.29 & 0.33 & 0.6 & 0.35 & 0.3 & 0.44 & 0.52 & 0.47 & 0.29 & 0.64 & 0.44 & 0.43 \\
\hline Service $\%$ & 0.54 & 0.54 & 0.46 & 0.62 & 0.44 & 0.35 & 0.6 & 0.69 & 0.46 & 0.33 & 0.42 & 0.6 & 0.36 & 0.32 & 0.46 \\
\hline
\end{tabular}


Annex: Table 5b: Mean Summary Statistics, by number age, 1999

\begin{tabular}{|c|c|c|c|c|c|c|c|c|c|c|c|c|c|c|c|}
\hline $\begin{array}{l}\text { Panel D: } \\
\text { Firm Age 3-10 }\end{array}$ & $\begin{array}{c}\text { Bosnia } \\
\text { Herzegovina }\end{array}$ & Bulgaria & Croatia & \begin{tabular}{c|} 
Czech \\
Republic
\end{tabular} & Estonia & Hungary & Latvia & Lithuania & Poland & Romania & $\begin{array}{c}\text { Russian } \\
\text { Federation }\end{array}$ & Slovakia & Slovenia & Ukraine & Yugoslavia \\
\hline \# Observations & 255 & 994 & 866 & 4,007 & 4,165 & 3,087 & 1,502 & 561 & 4,722 & 22,324 & 1,830 & 843 & 220 & 1,387 & 1,100 \\
\hline Firms $\%$ & 27 & 6 & 20 & 73 & 72 & 72 & 81 & 72 & 50 & 82 & 63 & 69 & 74 & 10 & 49 \\
\hline $\begin{array}{l}\text { Total \# } \\
\text { Employees }\end{array}$ & 27,024 & 166,183 & 144,327 & $1,107,965$ & 176,225 & 681,996 & 239,275 & 125,928 & $1,165,958$ & $2,248,700$ & $1,247,808$ & 484,720 & 58,397 & 761,965 & 213,814 \\
\hline Employees \% & 18 & 12 & 25 & 75 & 66 & 82 & 87 & 84 & 36 & 74 & 47 & 75 & 73 & 12 & 27 \\
\hline $\begin{array}{l}\text { Change in Total } \\
\text { Employment }\end{array}$ & . & $-15,367$ & 666 & . & -430 & $-2,411$ & 11 & $-17,864$ & $-30,702$ & $-127,419$ & $-37,468$ & . & . & $-169,155$ & 712 \\
\hline $\begin{array}{l}\text { Employees } \\
\text { (Average) }\end{array}$ & 106 & 167 & 167 & 277 & 42 & 221 & 159 & 224 & 247 & 101 & 682 & 575 & 265 & 549 & 194 \\
\hline Sales (U\$S) & 1354188 & 2017574 & 7567120 & 12854576 & 1001288 & 11045167 & . & 5231696 & 19036285 & 910315 & . & 11427585 & 41710687 & 330684802 & 6640705 \\
\hline Assets (U\$S) & 2462164 & 1561267 & 19462587 & 13252967 & 842567 & 7840641 & 3505550 & 5366607 & 19140611 & 854556 & 47821230 & 15771075 & 25814362 & 689800979 & 21364865 \\
\hline Age & 6.7 & 7.01 & 7.27 & 6.53 & 6.56 & 6.88 & 6.23 & 5.96 & 7.08 & 6.5 & 6.22 & 6.29 & 8.16 & 5.42 & 7.72 \\
\hline $\begin{array}{l}\text { Liabilities / } \\
\text { Equity }\end{array}$ & 1.31 & 2.03 & 6.5 & 2.59 & 2.45 & 2.01 & 2.21 & 1.58 & 2.53 & 3.84 & 1.79 & 2.85 & 1.54 & 0.51 & 1.7 \\
\hline Debt / Equity & 1.29 & 1.83 & 5.48 & 2.46 & 2.38 & 1.71 & 1.97 & 1.55 & 2.42 & 3.64 & 1.77 & 2.69 & 1.24 & 0.49 & 1.64 \\
\hline Acct Pay / Equity & 0.17 & 0.33 & . & 0.07 & 0.4 & 1.58 & 0.34 & 0.2 & 0.4 & 1.52 & 0.03 & 0.11 & . & 0.21 & 0.13 \\
\hline Current Ratio & 1.31 & 1.57 & 1.19 & 1.73 & 1.3 & 1.44 & 1.68 & 1.51 & 1.26 & 1.06 & 1.57 & 1.4 & 1.45 & 1.59 & 1.73 \\
\hline Cash Ratio & 0.06 & 0.26 & 0.07 & 0.32 & 0.24 & 0.21 & 0.2 & 0.12 & 0.17 & 0.14 & 0.13 & 0.19 & 0.05 & 0.05 & 0.06 \\
\hline $\begin{array}{l}\text { Fixed Assets / } \\
\text { Total Assets }\end{array}$ & 0.59 & 0.45 & 0.4 & 0.43 & 0.48 & 0.4 & 0.43 & 0.53 & 0.52 & 0.46 & 0.46 & 0.47 & 0.51 & 0.71 & 0.47 \\
\hline ROE & 0.05 & 0.07 & 0.17 & 0.11 & 0.05 & 0.2 & 0.18 & 0.15 & 0.18 & 0.43 & -0.23 & 0.04 & 0.06 & -0.01 & 0.01 \\
\hline ROA & 0.04 & 0.03 & 0.06 & 0.09 & 0.04 & 0.1 & 0.12 & 0.1 & 0.11 & 0.13 & 0.02 & 0.06 & 0.01 & 0.04 & 0.03 \\
\hline $\begin{array}{l}\text { 1-Yr Sales } \\
\text { Growth }\end{array}$ & . & 8.35 & -3.26 & -3.58 & -4.25 & 6.4 & . & 7.52 & -1.71 & -8.45 & . & -10.29 & . & 0.01 & 4.45 \\
\hline Agriculture \% & 0.11 & 0.12 & 0.03 & 0.05 & 0.11 & 0.06 & 0.03 & 0.03 & 0.02 & 0.11 & 0.02 & 0.05 & 0.01 & 0.2 & 0.06 \\
\hline Industry $\%$ & 0.37 & 0.47 & 0.38 & 0.42 & 0.37 & 0.64 & 0.35 & 0.44 & 0.47 & 0.56 & 0.47 & 0.46 & 0.51 & 0.36 & 0.46 \\
\hline Service $\%$ & 0.48 & 0.4 & 0.57 & 0.46 & 0.46 & 0.28 & 0.58 & 0.51 & 0.48 & 0.32 & 0.39 & 0.42 & 0.42 & 0.38 & 0.45 \\
\hline
\end{tabular}


Annex: Table 5c: Mean Summary Statistics, by number age, 1999

\begin{tabular}{|c|c|c|c|c|c|c|c|c|c|c|c|c|c|c|c|}
\hline $\begin{array}{l}\text { Panel E: } \\
\text { Firm Age 10+ }\end{array}$ & $\begin{array}{c}\text { Bosnia } \\
\text { Herzegovina }\end{array}$ & Bulgaria & Croatia & $\begin{array}{c}\text { Czech } \\
\text { Republic }\end{array}$ & Estonia & Hungary & Latvia & Lithuania & Poland & Romania & $\begin{array}{l}\text { Russian } \\
\text { Federation }\end{array}$ & Slovakia & Slovenia & Ukraine & Yugoslavia \\
\hline \# Observations & 591 & 678 & 923 & 297 & 311 & 37 & 4 & . & 3,138 & 1 & 400 & 93 & 52 & 1,868 & 974 \\
\hline Firms $\%$ & 63 & 4 & 22 & 5 & 5 & 1 & 0 & . & 33 & 0 & 14 & 8 & 18 & 13 & 44 \\
\hline $\begin{array}{l}\text { Total \# } \\
\text { Employees }\end{array}$ & 118,048 & 336,653 & 330,216 & 98,030 & 42,646 & 28,500 & 208 & . & $1,685,807$ & 4,247 & $1,070,802$ & 57,700 & 17,575 & $1,704,111$ & 534,005 \\
\hline Employees \% & 80 & 25 & 56 & 7 & 16 & 3 & 0 & . & 52 & 0 & 40 & 9 & 22 & 26 & 67 \\
\hline $\begin{array}{l}\text { Change in Total } \\
\text { Employment }\end{array}$ & . & $-30,565$ & $-18,090$ & . & $-3,407$ & 3,550 & -64 & . & $-183,627$ & $-1,586$ & $-26,707$ & . & . & $-255,296$ & 1,340 \\
\hline $\begin{array}{l}\text { Employees } \\
\text { (Average) }\end{array}$ & 200 & 497 & 358 & 330 & 137 & 770 & 52 & . & 537 & 4,247 & 2,677 & 620 & 338 & 912 & 548 \\
\hline Sales (U\$S) & 1294912 & 6473943 & 12994407 & 10868302 & 2181715 & 23493844 & . & . & 23472019 & 1948804 & . & 34710203 & 33301528 & 7758487 & 10020989 \\
\hline Assets (U\$S) & 4344298 & 8390845 & 30334009 & 18914219 & 3287843 & 17476916 & 700829 & . & 24258164 & 3123046 & 81768715 & 60426349 & 22665884 & 12361472 & 33476516 \\
\hline Age & 29.56 & 43.89 & 47.84 & 67.9 & 37.95 & 21.7 & 99 & . & 49.53 & 1999 & 58.2 & 21.23 & 34.17 & 55.75 & 50.87 \\
\hline $\begin{array}{l}\text { Liabilities / } \\
\text { Equity }\end{array}$ & 0.79 & 1.1 & 1.62 & 0.91 & 1.59 & 1.99 & 4.84 & . & 1.51 & -1.81 & 1.01 & 0.78 & 1.25 & 0.43 & 0.8 \\
\hline Debt / Equity & 0.77 & 0.93 & 1.18 & 0.88 & 1.53 & 1.86 & 4.81 & . & 1.42 & -0.35 & 1.01 & 0.75 & 1.05 & 0.42 & 0.78 \\
\hline Acct Pay / Equity & 0.11 & 0.17 & . & 0.02 & 0.34 & 1.75 & 0.31 & . & 0.37 & -0.17 & 0.03 & 0.05 & . & 0.21 & 0.11 \\
\hline Current Ratio & 1.28 & 1.82 & 1.41 & 2.05 & 1.37 & 1.43 & 1.07 & . & 1.35 & 1.36 & 1.55 & 1.65 & 1.55 & 1.75 & 2.09 \\
\hline Cash Ratio & 0.06 & 0.28 & 0.08 & 0.41 & 0.25 & 0.18 & 0.07 & . & 0.18 & 0.53 & 0.08 & 0.24 & 0.06 & 0.05 & 0.07 \\
\hline $\begin{array}{l}\text { Fixed Assets / } \\
\text { Total Assets }\end{array}$ & 0.72 & 0.6 & 0.6 & 0.62 & 0.63 & 0.58 & 0.33 & . & 0.5 & 0.45 & 0.52 & 0.63 & 0.56 & 0.85 & 0.58 \\
\hline ROE & 0.03 & 0.00 & -0.01 & 0.00 & 0.02 & 0.16 & 0.24 & . & 0.04 & 0.04 & -0.65 & -0.02 & 0.03 & -0.05 & 0 \\
\hline ROA & 0.04 & 0.01 & 0.02 & 0.03 & 0.03 & 0.08 & 0.06 & . & 0.06 & 0.37 & -0.17 & 0.03 & 0.01 & 0.03 & 0.03 \\
\hline $\begin{array}{l}\text { 1-Yr Sales } \\
\text { Growth }\end{array}$ & 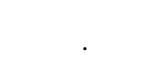 & -5.52 & -10.23 & -7.42 & -6.25 & -6.23 & . & . & -6.68 & -39.48 & . & -17.68 & . & -99.15 & -1.34 \\
\hline Agriculture \% & 0.11 & 0.03 & 0.04 & 0.17 & 0.07 & 0.06 & 0 & . & 0.01 & 0 & 0.02 & 0.33 & 0.04 & 0.26 & 0.09 \\
\hline Industry $\%$ & 0.54 & 0.71 & 0.58 & 0.35 & 0.38 & 0.65 & 0 & . & 0.64 & 1 & 0.79 & 0.28 & 0.73 & 0.54 & 0.59 \\
\hline Service $\%$ & 0.31 & 0.23 & 0.35 & 0.46 & 0.49 & 0.16 & 0.5 & . & 0.27 & 0 & 0.14 & 0.32 & 0.21 & 0.15 & 0.29 \\
\hline
\end{tabular}

